no.

GL-92-24

c. 2

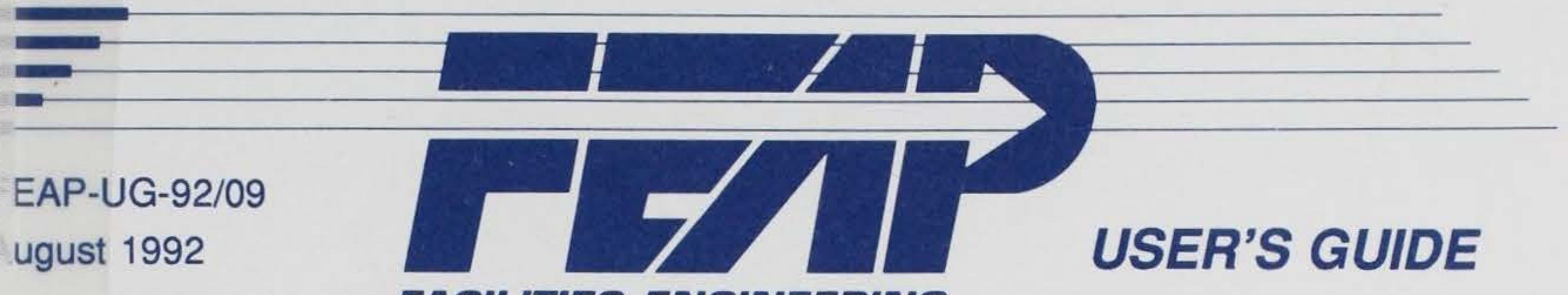

MP GL-92-24

\title{
USER'S GUIDE: SUBSURFACE DRAINAGE FOR MILITARY PAVEMENTS
}

\section{US-CE-C \\ UNITED STATES PROPERTY OF THE}

by

William P. Grogan

US Army Engineer Waterways Experiment Station

Vicksburg, MS 39180-6199

RESEARCH LIBRARY

JS ARMY ENGINEER WATERWAYS

EXPERIMENT STATION

VICKSBURG, MISSISSIPPI

Approved For Public Release; Distribution Is UnIImited

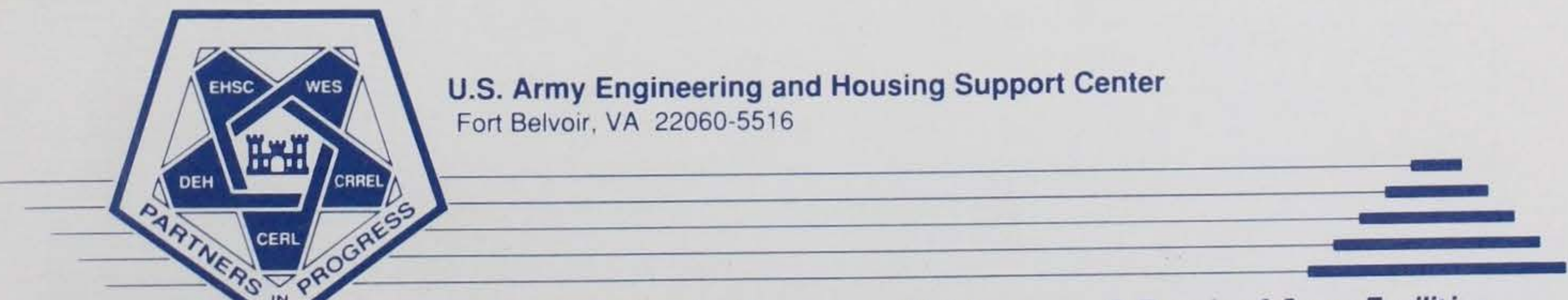

Innovative Ideas for the Operation, Maintenance, \& Repair of Army Facilities 
Public reporting burden for this coliection of information is estimated to average 1 hour per response, including the time for reviewing instructions, searching existing data sources. gathering and maintaining the data needed, and completing and reviewing the collection of information. Send comments regarding this burden estimate or any other aspect of this Davis Highway, Suite 1204. Arlington, VA 22202-4302, and to the Office of Management and Budget, Paperwork Reduction Project (0704-0188), Washington, DC 20503

\begin{tabular}{|l|l|l|}
\hline 1. AGENCY USE ONLY (Leave blank) & 2. REPORT DATE & 3. REPORT TYPE AND DATES COVERED
\end{tabular}

4. TITLE AND SUBTITLE

Auqust 1992

Final report

User's Guide: Subsurface Drainage for

Military Pavements

5. FUNDING NUMBERS

6. AUTHOR(S)

William P. Grogan

\section{PERFORMING ORGANIZATION NAME(S) AND ADDRESS(ES)}

USAE Waterways Experiment station

Geotechnical Laboratory

3909 Halls Ferry Road

Vicksburg, MS 39180-6199
8. PERFORMING ORGANIZATION REPORT NUMBER

Miscellaneous Paper GL-92-24

10. SPONSORING /MONITORING AGENCY REPORT NUMBER

FEAP-UG-92/09

US Army Corps of Engineers

Engineering and Housing Support Center

Bldg. 2593

Fort Belvoir, VA 22060-5516

\section{SUPPLEMENTARY NOTES}

12a. DISTRIBUTION/AVAILABILITY STATEMENT

12b. DISTRIBUTION CODE

Approved for public release; distribution is unlimited

13. ABSTRACT (Maximum 200 words)

Work conducted at the Corps of Engineers research laboratories has shown that subsurface pavement layers are virtually impermeable. The impermeable layers become saturated and remain saturated for virtually the life of the pavement. Saturation weakens subsurface layers and causes early deterioration of pavements. In order to reduce pavement deterioration caused by saturated subsurface layers, criterion has been established for the use of drainable subsurface layers. This criterion is contained in Engineering Technical Letter $1110-3-435$.

At Fort Campbell, Kentucky, a vehicle maintenance facility parking lot was constructed with a drainable base course. The expected benefits of constructing a pavement with a drainable base include improved pavement performance by reducing problems associated with saturated subsurface layers. Problems associated with saturated subsurface layers include pumping, erosion, subgrade weakening. frost heave, and freeze/thaw damage

14. SUBJECT TERMS

See reverse.

\begin{tabular}{|l|l|l|l|l}
\hline $\begin{array}{l}\text { 17. SECURITY CLASSIFICATION } \\
\text { OF REPORT } \\
\text { Unclassified }\end{array}$ & $\begin{array}{c}\text { 18. SECURITY CLASSIFICATION } \\
\text { OF THIS PAGE } \\
\text { UnClassified }\end{array}$ & $\begin{array}{c}\text { 19. SECURITY CLASSIFICATION } \\
\text { OF ABSTRACT } \\
\text { Unclassified }\end{array}$ & $\begin{array}{l}\text { 20. LIMITATION OFABSTRACT } \\
\end{array}$
\end{tabular}


14. SUBJECT TERMS: (Continued)

Coefficient of Permeability Dense Graded

Drainable Layers

Gradation

Impermeable
Open Graded Material

Permeability

Rapid Draining Material Saturation

stability 


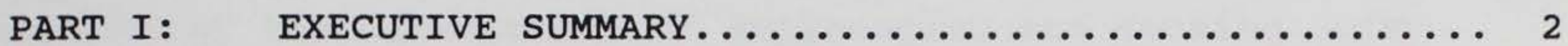

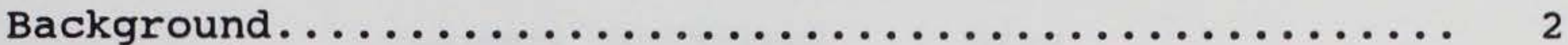

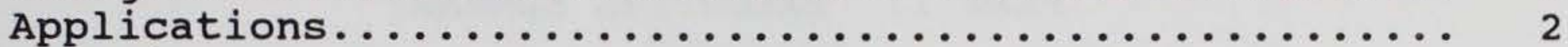

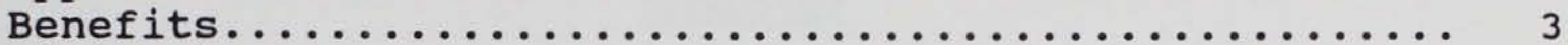

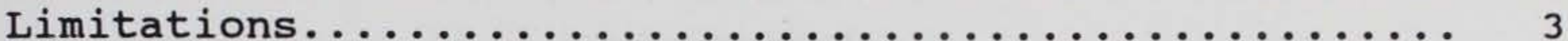

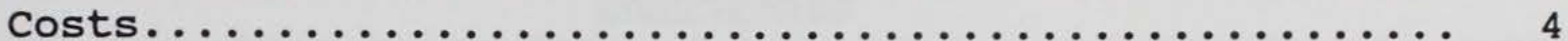

Recommendation for Use...................... 4

Points of Contact.......................... 4

PART II: PREACQUISITION...................... 6

Description of Free Draining Bases............... 6

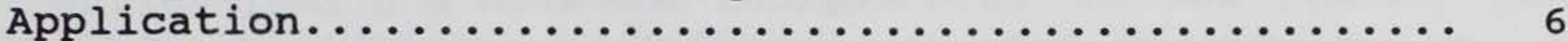

Limitations/Disadvantages.................... 7

Demonstration/Implementation Sites................ 8

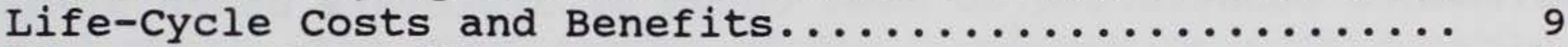

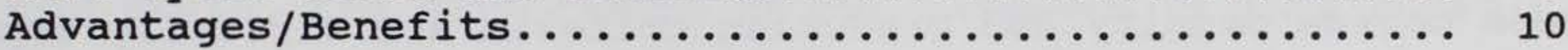

PART III: ACQUISITION/PROCUREMENT ................ 12

Potential Funding sources.................... 12

Technology Components and Sources................. 13

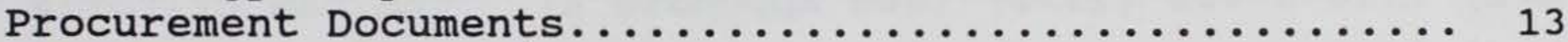

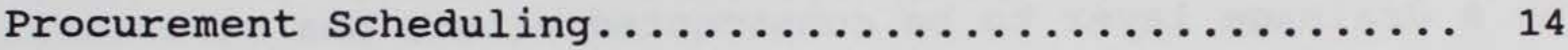

PART IV: POST ACQUISITION..................... 15

Initial Implementation...................... 15

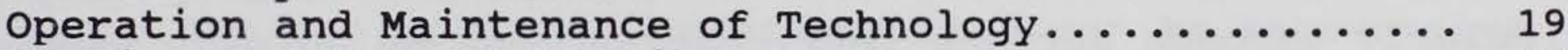

Service and support Requirements.................. 20

Performance Monitoring....................... 20

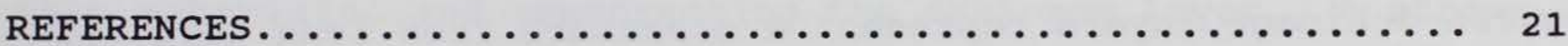

TABLES $1-2$

FIGURES 1-3

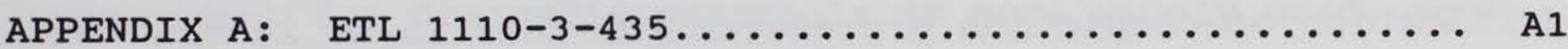

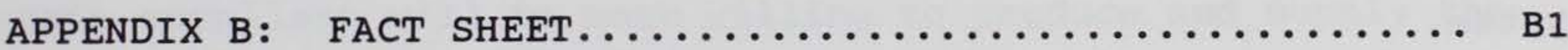


USER'S GUIDE: SUBSURFACE DRAINAGE FOR MILITARY PAVEMENTS

PART I: EXECUTIVE SUMMARY

\section{Background}

Research conducted at the US Army Engineer Waterways Experiment station (WES), the Construction Engineering Research Laboratory (CERL), and the Cold Regions Research and Engineering Laboratory (CRREL) has shown that bases and subbases for military pavements constructed to meet Corps of Engineers dense graded base course density and gradation criteria are virtually impermeable. Therefore, new criteria that provide for rapid draining of base courses have been set forth in Engineer Technical Letter (ETL) 1110-3-435 (1992) (see Appendix A). The new criteria call for a drainage layer to be constructed within the structural section of the pavement system. By providing a drainage layer in the pavement system, moisture entering the pavement system, particularly through surface infiltration, can be quickly removed. The specification and $\mathrm{QC} / \mathrm{QA}$ procedure for constructing base course drainage layers represent a departure from long term endproduct specifications for compaction in military construction. A process specification is used. This requires real time visual verification of compaction procedures for this layer in the system.

\section{Application}

The requirements set forth in ETL 1110-3-435 are applicable to all Headquarters, US Army Corps of Engineers (HQUSACE) elements and field operating activities (FOA) having Army and Air Force military construction design responsibility. The information in ETL 1110-3-435 provides guidance for all pavements located in both frost and nonfrost areas. The use of the guidance for flexible pavement roads, streets, or parking areas 
having a structural thickness less than $8 \mathrm{in.} \mathrm{is} \mathrm{optional.} \mathrm{This}$ ETL is advisory only for projects where design is the responsibility of the Directorate of Engineering and Housing (DEH).

\section{Benefits}

The benefits to be derived from using drainage layers within the structural system of the pavement is that performance of the pavement will be greatly improved. Drainage layers provide a means of quickly dispelling moisture that infiltrates the surface of the pavement system. By reducing the time the subsurface layers of a pavement system are saturated, thereby creating a weakened state, the performance of the pavement is considerably improved. This improved performance can be directly realized in dollar savings through the extended life and reduced maintenance required to maintain pavements with drainage layers.

\section{Limitations}

There are two primary limitations that can be encountered when using drainage layers for pavements: obtaining the necessary materials, and constructing the drainage layer. A strong durable crushed clean aggregate is required for drainage layers. In some areas this may be difficult to obtain. However, as the requirement for drainable materials is more widely used, aggregate suppliers will be more willing to produce and supply the materials necessary. The construction of drainable layers requires that some special considerations and care be taken by the contractor. Once a contractor has constructed pavements with drainable materials, the initial difficulties that the contractor may have experienced are usually overcome.

Because there is no adequate procedure to verify that the contractor has performed the contract requirements after the drainage layer has been constructed, the QA/QC is a change from an end-product to a process compaction specification for the layer. The Government $\mathrm{QA}$ personnel need to be particularly aware 
of this change in $\mathrm{QA} / \mathrm{QC}$ to ensure that he is on site to witness the construction of the drainage layer.

\section{Costs}

There may be an increase in cost per ton of drainable base materials because of increased costs to produce the material. However, the square yard yield is greater per ton for the less dense drainable material than for dense graded material. There is also an increased cost for rigid pavements, because until the requirement for drainable layers was instituted, in-situ subgrade materials were often used as the foundation for rigid pavements. However, the expected increase in pavement performance through the elimination of pumping, erosion, subgrade weakening, and freeze/thaw damage justifies the requirement for drainage layers under rigid pavements.

\section{Recommendation for Use}

It is recommended that drainable bases be used for new construction of and reconstruction of all pavements that have any damage potential due to saturated subsurface layers. In general, all pavements have a potential for damage due to saturated subsurface pavement layers. However, in nonfrost areas with a subgrade permeability greater than $20 \mathrm{ft} /$ day, it can be assumed that the vertical drainage is adequate and that no drainage layer is necessary. Also, a drainage layer in a flexible pavement with a design structural thickness less than 8 in. is optional.

\section{Points of contact}

Point of contact regarding this technology include the following: 
Technical:

Director

US Army Engineer Waterways Experiment Station

ATTN: CEWES-GP-T (Mr. William P. Grogan)

3909 Halls Ferry Road

Vicksburg, MS 39180-6199

Telephone: (601) 634-2226

Facsimile: (601) 634-3020

US Army Engineering and Housing Support Center:

Commander

US Army Engineering and Housing Support Center

ATTN: CEHSC-FB-P (Mr. Joseph Sicuranza)

Fort Belvoir, VA 22060-5516

Telephone: (703) 704-1575/1576

Facsimile: (703) 704-1610

Point of contact at installation where the demonstration project was conducted:

Area Engineer office

Building 2180

13 A Street ATTN: (Mr. Cliff Harnage)

Fort Campbell, KY 42223

Telephone: (502) 798-7222 


\section{Description of Free Draining Bases}

A free draining base course provides a way for water entering the structural system of a pavement to escape rapidly without damaging the pavement. Dense graded base courses historically required by the corps of Engineers provide stable platforms for construction and provide strong structural layers as long as they remain unsaturated. However, dense graded base courses do not always remain unsaturated for the life of a pavement. In fact, once a dense graded base course becomes saturated, it is very difficult for any water to exit the system. Problems that result from saturated base courses include pumping, erosion, subgrade weakening, frost heave, and freeze/thaw damage.

Dense graded base courses contain a great deal of fines which block drainage paths. Free draining materials restrict the quantity of fines that are allowed. By restricting the quantity of fines, open drainage paths are provided. The open drainage paths in a free draining material allow water to drain quickly before damage can occur if a slope is provided.

In order to ensure that maximum benefit is derived from the free draining material, it is generally located as low in the structural section of the pavement as possible. Materials above the free draining material have the quantity of fines restricted, not as greatly as the free draining material, to ensure that the free draining layer does not become clogged and therefore reduce its benefit to the pavement system. Both the layers above and below the free draining layer must meet filter criteria as defined in ETL 1110-3-435.

\section{Application}

Free draining layers are applicable to virtually all military pavements. A drainage layer is optional in flexible pavements with a structural thickness less than 8 in. Also, 
pavements in nonfrost areas with subgrade permeabilities greater than $20 \mathrm{ft} /$ day do not require a drainage layer. If the subgrade permeability is greater than $20 \mathrm{ft} /$ day, it is assumed that the vertical drainage is adequate to prevent the structural section from remaining in a saturated condition for extended periods of time. ETL 1110-3-435 specifically defines the circumstances requiring a free draining layer in a pavement system.

\section{Limitations/Disadvantages}

There are two limitations to using a free draining layer in a pavement system: obtaining a source of materials that meet the requirements, and finding a contractor with experience constructing pavements with free draining layers.

The specifications are very stringent for materials that meet the requirements necessary to provide a stable, durable drainage layer. In order to produce free draining materials, producers may have to include additional steps in processing their raw materials. This can be costly, and some producers are reluctant to change their setup until there is a great demand for it. One or two small jobs requiring materials that meet the specifications of a free draining base may not provide enough incentive for a producer to change operations. When it is too difficult to obtain a material, the designer should investigate to find out all the gradations that are locally produced. There may be a locally produced gradation that is used for another application that can also be used as a free draining base course material.

Contractors without experience constructing free draining bases sometimes find it very difficult to place, compact, and then construct the next layer in the system on the surface of a free draining base. However, with time and patience, the proper techniques can be learned, and a quality product will result. 


\section{Demonstration/Implementation Sites}

In 1990 a demonstration project was conducted at Fort Campbell, Kentucky. In this demonstration a vehicle maintenance yard parking area was constructed with a base course drainage layer. The pavement section at Fort Campbell is shown as a schematic in Figure 1.

The pavement section at Fort Campbell consisted of 9.5 in. of free draining material directly beneath a 3.5-in. asphalt concrete surface course. The drainage layer had an average slope of approximately 1.5 percent with a minimum slope of 1.0 percent. The minimum slope of 1.0 percent is less than what is recommended for this type of pavement. Also, ETL 1110-3-435 suggests that a dense graded aggregate base be constructed between the free draining base and the asphalt concrete surface course. However, because of the length of the drainage path and slope of the pavement, the design required a relatively thick drainage layer. If additional outlet drainage and additional slope could have been provided, thereby reducing the length and time for drainage to occur, the thickness of the drainage layer could possible have been reduced.

Figure 2 shows a plan view of the construction site. Drainage of the free draining layer was provided through the sides of the four drop inlets shown in Figure 2. A plan view and section view showing the drainage system around the drop inlets is shown in Figure 3.

The contractor did have some difficulty placing the 9.5-in.thick drainable base. The material used for the free draining layer was a Kentucky 57 stone which has virtually the same gradation as an ASTM 57 stone. This is a very open gradation. A choke stone was to be placed on the top of the drainage layer to provide stability for construction equipment. However, because the drainage layer was over 6 in. thick, the specifications required that it be placed in two lifts to ensure that proper compaction was obtained. This required that the contractor work on the unstabilized layer to place the second lift of the 
drainage layer. The contractor found this very difficult. As an alternative, the contractor tried placing one 9.0-in. lift (9.0 in. was the maximum thickness the contractor's equipment could place) of the 57 stone and then a 1.0-in. lift of choke stone to stabilize the surface. The contractor intended to work $0.5 \mathrm{in}$. of choke stone into the 57 stone and leave $0.5 \mathrm{in}$. on the surface. Because this was a relatively small job, the contractor did not have enough time to develop a construction methodology satisfactory to himself and the corps. The author's opinion is that the 9.0-in. layer is too thick to ensure compaction throughout the layer. Also, the 1.0-in.-thick choke stone layer is too thick, and the 0.5-in. layer left on the surface may eventually work its way into the 57 stone, thereby reducing the thickness of the section. The contractor felt that it was too difficult to work on a layer of unstabilized 57 stone. However, contractors have constructed on unstabilized 57 stone in the past without problems. The best compromise for this job would probably have been to blend the 57 stone with the choke stone. The permeability of the bend would not have been significantly less than the 57 stone alone; however, the stability for construction on the blend would have been greatly improved over the stability of the 57 stone.

The pavement has been in service for over a year without any problems. Water is freely draining from the base course and has been since the pavement was constructed. Instrumentation was installed at one of the out-fall points for the base course drainage system. An interesting observation made was that although asphalt concrete pavements are normally considered impermeable, a large quantity of water has been permeating the new asphalt concrete pavement and draining through the free draining base course ever since the pavement was constructed.

\section{Life-cycle costs and Benefits}

Because of the limited use of free draining base courses for military pavements, there does not exist enough data to perform a 
life cycle cost analysis comparing military pavements without free draining bases to those with free draining bases. However from the literature, states and municipalities that have used free draining bases expect substantial savings through increased service life and reduced maintenance costs. Some estimators expect increased service life from 33 percent (Cook 1991) to as much as 300 to 400 percent (Cedegren 1987).

An increase in service life is expected when using a free draining base course. Dense graded base courses become saturated for long periods of time because they do not allow water to drain. During these long periods of saturation, the strength of the dense grade base course and the top part of the subbase or subgrade in contact with it are greatly reduced. Free draining materials can become saturated, but the water is quickly dissipated. Therefore, the amount of time the free draining materials are in a weakened state due to saturation is greatly reduced. The reduced amount of time the pavement is in a weakened state adds directly to the life of the pavement.

A significant reduction in maintenance costs would be expected with pavements having free draining bases. The free draining course provides a reduction or elimination of pumping, erosion, subgrade weakening, frost heave, and freeze/thaw weakening. The reduction or elimination of these problems requires that much less maintenance be performed on the pavement.

\section{Advantages/Benefits}

The advantages and benefits of constructing a pavement with a free draining base course include extended service life and reduced maintenance. These benefits are a primary result of the bases insensitivity to saturation. The free draining materials provide a base course that drains rapidly, within hours. Dense graded base courses drain slowly, within weeks to months, and sometimes they never drain over the life of the pavement. The long periods of saturation result in long periods of reduced 
strength. The long periods of reduced strength relate directly to reduced pavement performance. 


\section{Potential Funding Sources}

Typically, installations fund the construction of small section of new pavements and the reconstruction of deteriorated pavements out of their annual budgets. Major new construction would be a MILCON project. Construction of pavements with free draining base courses may qualify for dedicated funds authorized under special incentive programs. Listed below are some examples of funding sources. All of the sources listed may not apply to the construction of pavements with drainable bases, but are included for consideration on other projects.

a. Productivity Program. See AR 5-4, Department of the Army Productivity Improvement Program for guidance to determine if the project qualifies for this type of funding.

b. Facilities Engineering Applications Program (FEAP). In the past, a number of pavement and railroad maintenance projects located at various installations were funded with FEAP demonstration funds. At that time, emphasis was placed on demonstrating new technologies to the DEH community. Now that these technologies have been demonstrated, the installations will be responsible for funding their projects through other sources. However, emphasis concerning the direction of FEAP may change in the future; therefore, FEAP should not be ruled out as a source of funding.

c. Special programs. Examples of these are as follows:

(1) FORSCOM program to provide facility repairs to support mobilization which may include rehabilitation of airfields or other pavements.

(2) Safety program which may include the repair of unsafe/deteriorated pavements.

(3) Security upgrade which may include the repair or enlargement of fencing.

d. Reimbursable customer. Examples of this source are roads to special function areas such as family housing or schools and airfield pavements required to support logistical operations.

e. Special requests from MACOMS.

f. Year end funds. This type funding should be coordinated with the MACOMS to ensure that the funds will not 
be lost after a contract is awarded (funding source request that funds be returned).

g. Operations and Maintenance Army. These are the normal funds used for funding pavement and railroad projects.

\section{Technology Components and Sources}

Components of this technology which must be procured for constructing a pavement with a drainable base course are section design, drainage design, drainage collection design, plans, and specifications (may be done in-house or contracted out), pavement construction contractor, drainable material for the drainage layer, and materials for the remainder of the pavement section.

Items normally used in the construction of pavements are applicable to the construction of drainable subsurface courses. The materials used for drainage layers are not always readily available. It may be necessary to contact local aggregate suppliers to ensure that they can and will supply the gradations necessary to fulfill the specification requirements. other sources of information available to the DEH are state Departments of Transportation and the Engineering Division of the supporting Corps district office. The procedures for constructing a pavement with a drainage layer may require stricter control than the procedures for constructing a pavement without a drainage layer.

\section{Procurement Documents}

Pavement construction with a drainable base course is a site specific activity, and a standard specification is not available. However, ETL 1110-3-435 states the requirements for materials to be used as free draining base courses. The ETL also provides information on construction techniques and requirements. Corps of Engineers Guide Specifications (CEGS) No. 02233, GradedCrushed-Aggregate-Base Course (1984) can be modified according to the requirements in ETL 1110-3-435. 
CEGS 02410 (1988), Subdrainage System, should be used for specifying the requirements of the subdrainage system that must be constructed to provide a means of dispelling the moisture from the free draining base course. Note that ETL 1110-3-435 requires a minimum of 6-in. diameter pipes be used for the subsurface drainage system. Copies of the CEGS can be obtained from the supporting corps district office.

\section{Procurement Scheduling}

There are no long lead time items that must be procured for construction of pavements with drainable layers. However, it is prudent to contact local aggregate suppliers to ensure that the specified aggregate can be supplied. The time required and methods used to prepare project plans and specifications are similar to the requirements for pavements with dense graded base courses. 


\section{Initial Implementation}

\section{Equipment}

No special equipment is required to construct a pavement with a drainable subsurface course. Conventional paving equipment such as an asphalt paver is used to place the materials for the drainage layer. The courses that are placed on the drainage layer are constructed in the conventional methods of constructing base and surface courses as appropriate. However, tracked pavers, as opposed to wheeled pavers, provide stability and must be used to construct on the surface of the drainage layer. The drainage layer is designed to be stable enough to support other construction equipment, such as haul trucks. However, construction traffic should be kept to a minimum, and drivers should be cautioned to avoid sharp turns, sudden breaking, and acceleration on the surface of the drainage layer. All unnecessary traffic should be banned from operating on the exposed drainage layer. Extraneous traffic can damage the uncovered drainage layer. The pavement layer to be constructed over the drainage layer should be placed as soon as possible after the construction of the drainage layer in order to protect the drainage layer from possible damage.

\section{Material}

The materials used for the layers of the pavement system other than the drainage layer are the same as would be used for a pavement without a drainage layer with the following exceptions: If a base course is to be constructed on top of the drainable layer, material meeting the requirements of the Corps of Engineers dense graded base course (Headquarters, Department of the Army 1978) should be used with the fines (minus Us No. 200 standard Sieve) limited to 8 percent maximum, and the drainable base course material should be constructed on a 4-in. minimum thickness separation layer located between the drainage layer and the subgrade. The separation layer can be considered a subbase. The 
separation layer should meet the material requirements for a 50 CBR Corps of Engineers subbase course (Headquarters, Department of the Army 1978). Both the separation layer under the free draining course and the base course over the free draining course must meet the filter criteria defined in ETL 1110-3-435.

Materials that may be used as a drainage layer are divided into two categories, Rapid Draining Material (RDM) and open Graded Material (OGM). An RDM has a coefficient of permeability between 1,000 to $5,000 \mathrm{ft} /$ day and has the stability to support construction equipment and the structural strength to serve as a base or a subbase. An OGM has a coefficient of permeability greater than 5,000 ft/day and will normally require stabilization for stability or for structural strength to serve as a base in a flexible pavement. Gradations and material properties for the RDM and OGM are given in Tables 1 and 2 , respectively.

Drainable base materials that are not stable under construction equipment may be stabilized mechanically or with a binder. Mechanical stabilization can be accomplished with a choke stone. The gradation of a typical choke stone is shown in Table 1. Cement or asphalt can be used as binders to stabilize an unstable drainage material. The amount of asphalt or cement used to stabilize the drainable material is limited to the amount necessary just to coat the aggregate. The voids of the drainable material are not filled with binder, and the permeability of the stabilized drainable material is not significantly less than the permeability of the unstabilized drainable material.

Additional material requirements are detailed in ETL 1110-3-435.

\section{Personnel}

Regular pavement construction personnel are used for the construction of the drainage layer as well as the other layers in the pavement system. The first time a contractor constructs a pavement with a drainage layer, some difficulties may be experienced. However, given experience and following known procedures for the construction of drainage layers, the contractor should be able to provide a quality product. 
Although construction personnel are not different for constructing a drainable base course, there are added responsibilities for the Government $Q A$ inspection personnel. Because the construction of a drainable base requires a process specification, the QA person must be on the jobsite when the drainage layer is constructed to visually verify that the contractor follows the procedures detailed in the project specifications.

Visual monitoring of the construction process is required because there is not an adequate method of verifying the end results of the construction procedure.

\section{Procedure}

Due to the expected benefit from providing a drainage layer in a pavement system, ETL 1110-3-435 requires that virtually all new Corps constructed pavements and reconstructed pavements include a drainable layer in the pavement section.

Once it has been determined that the pavement design will include a drainable base, provisions in the design must be made to ensure that the out-fall from the drainable base is properly handled. To ensure that the drainable base drains, the base course must have adequate slope. The slope of the base course is required to be the same as the slope of the surface course. TM 5-820-1 (Headquarters, Department of the Army 1987) requires a minimum slope of 1.5 percent except for rigid pavements which must have a slope of 1.0 percent. A system must be included in the design that will collect the water coming from the base at low points and properly dispose of it.

The step-by-step procedure for constructing a pavement with a drainage layer is the same as that of constructing a pavement without a drainage layer. Some considerations that need to be taken when constructing the drainage layer include the following:

a. The surface that the drainage layer is to be constructed on (either the subgrade, a subbase, or a separation layer) must be hard and dense and meet the filter criteria detailed in ETL 1110-3-435. It may be necessary to use a geotextile to meet the filter criteria; however, the support material under the geotextile still needs to be hard and dense to provide adequate support to compact against the drainage layer. 
b. The grade of the surface that the drainage layer is to be constructed on must be true and constructed with the proper slope. It is important that the surface of the layer supporting the drainage layer be properly graded and sloped to prevent the supporting layer from holding water and to ensure that the drainage layer drains properly.

c. The drainable material must be placed in such a manner as to prevent segregation and provide a layer of uniform thickness. This can usually be accomplished by using an asphalt concrete paving machine to lay down the drainage layer.

d. The maximum lift thickness when placing the drainage layer should not be greater than 6 in. The maximum 6-in. lift requirement is to ensure density, after specified compaction, because there is not an adequate method for measuring the density of drainable base materials.

e. Because of the inability to measure density, compaction control normally used in pavement construction is not appropriate for materials such as the RDM or OGM. Therefore, compaction technique and level of effort must be specified for drainable base materials. The recommended method of determining the required compaction effort is to construct a test section and closely monitor the aggregate during compaction to determine when crushing of the aggregate appears excessive.

Nuclear gage readings can be used to reference the density obtained in the drainage layer test section with the drainage layer constructed in the pavement section. Experience has indicated that six passes or less of a 10-ton vibratory roller provides sufficient compactive effort. Materials that are not stabilized with asphalt or cement should be kept moist during compaction.

f. If a choke stone is used to stabilize an OGM, a maximum of $0.5 \mathrm{in}$. should be placed with a paver or spreader box on the final lift of the OGM. The choke stone is worked into the OGM with one to three passes of a 10-ton vibratory roller and by wetting.

g. If the drainable material is to be stabilized with asphalt, the asphalt must be allowed to cool to less than $200^{\circ} \mathrm{F}$. The asphalt must be allowed to cool to prevent excess shoving from occurring during compaction.

h. Once the drainage layer has been placed and compacted, the layer immediately above the drainage layer should be placed as soon as possible. The drainage layer can be fouled from dirt and dust getting into the drainage layer, clogging it, reducing its permeability and therefore reducing its effectiveness. Also, excess construction traffic can rut and shove the drainable 
layer. The surface layer provides confinement that prevents the drainage layer from rutting and shoving.

A drainage system must be constructed to collect and dispose of the water that will flow out of the drainable base course. If the drainage system is to be constructed under the shoulder or the edge of the pavement, it can be constructed either before or after the rest of the pavement has been constructed. If the drainage system is to be under the pavement as it was at the demonstration site, it must be constructed before the drainage layer is constructed. ETL 1110-3-425 contains typical details for placement of subsurface drainage systems with minimum values for clearances and coverage for the drain pipes. The materials used for the subdrainage system must be at least as permeable as the materials used in the drainage layer and meet filter criteria with adjacent materials. A minimum of a 6-in.-diam perforated pipe should be used for collecting the outflow from the base. Solid walled pipes should be used to dispose of the water collected in the perforated pipes. Materials such as concrete should be used for end walls to prevent crushing of the outlet pipe. The end wall should be flagged or constructed in such a way as not to interfere with mowing or maintenance operations. Rodent screens should be used to prevent wildlife from inhabitating the drainage pipes.

\section{operation and Maintenance of Technology}

Operation and maintenance of a pavement with a drainage layer are virtually no different than for a pavement without a drainage layer with one exception; the subsurface drainage system, which is installed to allow the water to escape from the drainage layer, must be inspected periodically and cleaned when necessary.

It is recommended that the subsurface drainage system be inspected at the same time the drainage system for the surface water or at a minimum of once a year, whichever is more frequent. Drain outlets need to be checked to ensure they are not clogged, 
crushed, or prohibit the outflow of water in any way. The subsurface lines should be checked through access holes and flushed if any sediment buildup has occurred. The source of any continued sediment needs to be investigated and corrected. Any pavements planned to be constructed in the same area as a pavement with a continuous out-flow of sediments needs to address the problem to ensure that it does not occur in the planned project.

\section{Service and Support Requirements}

No special services or support is required to implement or maintain this technology.

\section{Performance Monitoring}

The performance of the pavement can be monitored using a pavement management system which the installation should have in-place. This involves keeping records of pavement condition surveys and any maintenance and repair work done on the pavements. 


\section{REFERENCES}

Cook, M. and Dykins, S. 1991 (May). "Treated Permeable Base offers Drainage, Stability," Roads and Bridges. Vol 29 No. 5, Des Plaines, IA.

Cedegren, H. R. 1987 (Apr). "Undrained Pavements: A Costly Blunder," Civil Engineering. New York, NY.

Headquarters, Department of the Army. 1991. "Rapid Draining Base Courses For Pavements," Engineering Technical Letter ETL 1110-3-435, Washington, DC.

1988. "Subdrainage System," Corps of Engineers Guide Specification 02410, Washington, DC.

- 1984. "Graded-Crushed-Aggregate Base Course," Corps of Engineers Guide Specification 02233, Washington, DC. 1978 (Aug). "Flexible Pavement Design For Air-

fields," Army Technical Manual TM 5-825-2, Washington, DC. - 1987 (Aug). "Surface Drainage Facilities For Airfields and Heliports," Army Technical Manual TM 5-820-1, Washington, DC. 
Table 1

Gradations for Materials for Drainage Layers and Choke Stone

\begin{tabular}{||c|c|c|c||}
\hline \multirow{2}{*}{$\begin{array}{c}\text { Sieve } \\
\text { Designation } \\
\text { (in.) }\end{array}$} & \multicolumn{2}{|c|}{ Drainage Layer Material (\% Passing) } \\
\cline { 2 - 4 } & $\begin{array}{c}\text { Rapid Draining } \\
\text { Material }\end{array}$ & $\begin{array}{c}\text { Open Graded } \\
\text { Material }\end{array}$ & $\begin{array}{c}\text { Choke } \\
\text { Stone }\end{array}$ \\
\hline \hline $1-1 / 2$ & 100 & 100 & 100 \\
\hline 1 & $70-100$ & $95-100$ & 100 \\
\hline $3 / 4$ & $55-100$ & -- & 100 \\
\hline $1 / 2$ & $40-80$ & $25-80$ & 100 \\
\hline $3 / 8$ & $30-65$ & -- & $80-100$ \\
\hline No. 4 & $10-50$ & $0-10$ & $10-100$ \\
\hline No. 8 & $0-25$ & $0-5$ & $5-40$ \\
\hline No. 16 & $0-5$ & - & $0-10$ \\
\hline
\end{tabular}

Table 2

Material Properties for Drainage Layers

\begin{tabular}{||l|c|c||}
\hline \multicolumn{1}{|c||}{ Property } & $\begin{array}{c}\text { Rapid Draining } \\
\text { Material }\end{array}$ & $\begin{array}{c}\text { Open Graded } \\
\text { Material }\end{array}$ \\
\hline \hline $\begin{array}{l}\text { Coefficient of } \\
\text { Permeability ft/day }\end{array}$ & $1,000-5,000$ & $>5,000$ \\
\hline Effective Porosity & 0.25 & 0.32 \\
\hline $\begin{array}{l}\text { Percent Fractured } \\
\text { Faces (COE method) }\end{array}$ & $\begin{array}{l}90 \% \text { for } 80 \text { CBR } \\
75 \% \text { for } 50 \text { CBR }\end{array}$ & $\begin{array}{c}90 \% \text { for } 80 \text { CBR } \\
75 \%\end{array}$ \\
\hline C 50 CBR \\
\hline LA Abrasion & $>3.5$ & $<40$ \\
\hline Note: C is the uniformity coefficient $=\mathrm{D}_{60} / \mathrm{D}_{10}$ \\
\hline
\end{tabular}




\begin{tabular}{|c||}
\hline 3.5-in. Hot Mix Asphalt Concrete \\
\hline 9.5 -in. Free Draining Base with Choke Stone \\
1.0 percent minimum slope \\
$4.5-$ in. Dense Graded Aggregate Subbase \\
Cut, Fill and Compacted Subgrade \\
\hline
\end{tabular}

Figure 1. Schematic of pavement section at Fort Campbell, Kentucky demonstration site 


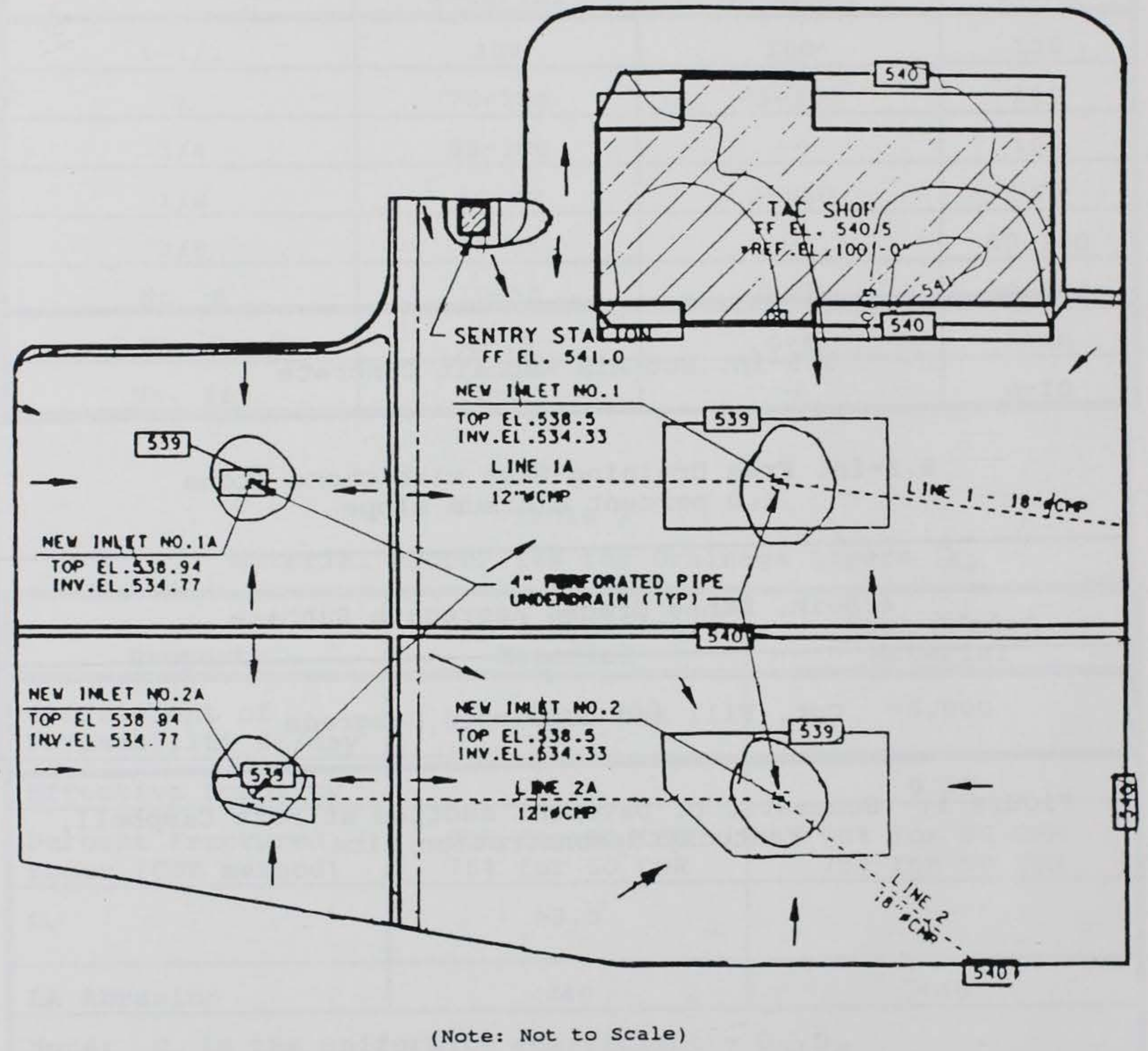

Figure 2. Plan view of demonstration site at Fort Campbell, Kentucky 


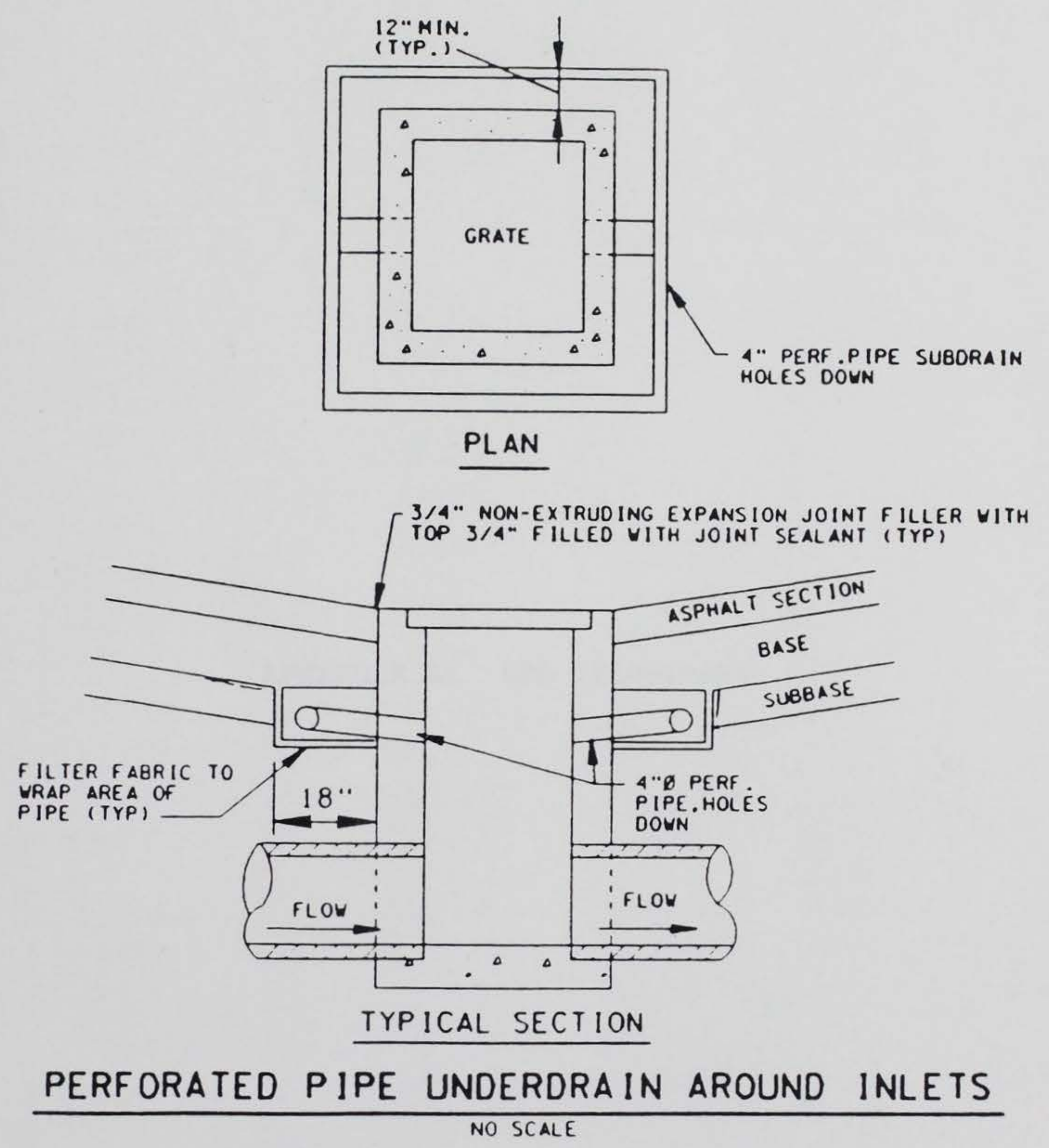

Figure 3. Plan and section of drop inlet detail with base course drainage 
APPENDIX A: ETL 1110-3-435 
Engineer Technical

Letter 1110-3-435

1 May 1992

\section{Engineering and Design \\ DRAINAGE LAYERS FOR PAVEMENTS}

1. Purpose. This letter updates guidance for design and construction of subsurface drainage features for Army and Air Force pavements. The guidance supersedes guidance provided in TM 5-820-2/AFM 88-5, Chap. 2 for design of subsurface drainage layers in pavements.

2. Applicability. This letter is applicable to all HQUSACE elements, major subordinate commands, districts, laboratories and separate field operating activities (FOA) having Army and Air Force military construction design responsibility and proviles guidance for all pavements located in both frost and nonfrost areas. The use of the guidance for flexible pavement roads, streets, or parking areas having a structural thickness less than 8 in. is optional.

\section{References.}

a. TM 5-818-2/AFM 88-6, Chap. 4, Pavement Design for Seasonal Frost Conditions.

b. TM 5-820-2/ARM 88-5, Chap. 2, Drainage and Erosion Control: Subsurface Drainage Facilities for Airfields.

c. TM 5-822-2/AFM 88-7, Chap. 5, General Provisions and Geometric Design for Roads, Streets, Walks, and open Storage Areas.

d. TM 5-822-5/ARM 88-7, Chap. 3, Flexible Pavement for Roads, Streets, Walks, and Open Storage Areas.

e. TM 5-822-6/AFM 88-7, Chap. 1, Rigid Pavements for Roads, Streets, Walks, and open Storage Areas.

f. TM 5-825-2/AFM 88-6, Chap. 2, Flexible Pavement Design for Airfields.

g. TM 5-825-3/AFM 88-6, Chap. 3, Rigid Pavements for Airfields.

4. Background. Research conducted at the US Army Engineer Waterways Experiment Station (WES), The Construction Engineering Research Laboratories (CERL), and the Cold Regions Research and 
ETL $1110-3-435$

1 May 92

Engineering Laboratory (CRREL) has shown that bases and subbases for military pavements constructed to meet Corps of Engineers density and gradation criteria are virtually impermeable. In a study conducted for CERL, Mr. Harry $R$. Cedergren concluded that most airfield pavements have poor subsurface drainage and that joint and surface sealing and repair programs are not able to keep surface water out of the structural sections. Based on extensive literature reviews and field surveys, it has been found that the permeability of a good drainage layer should be in the order of 1,000 to $10,000 \mathrm{ft} /$ day. To ensure military pavements have adequate drainage, the criteria provided in the enclosed technical guidance is to be used for design and construction of subsurface drainage aspects of pavements.

5. Action to be Taken. The guidance in Enclosures 1 and 2 should be used for design and construction of the subsurface drainage layers for all Army and Air Force pavements.

FOR THE DIRECTOR OF MILITARY PROGRAMS:

Encls

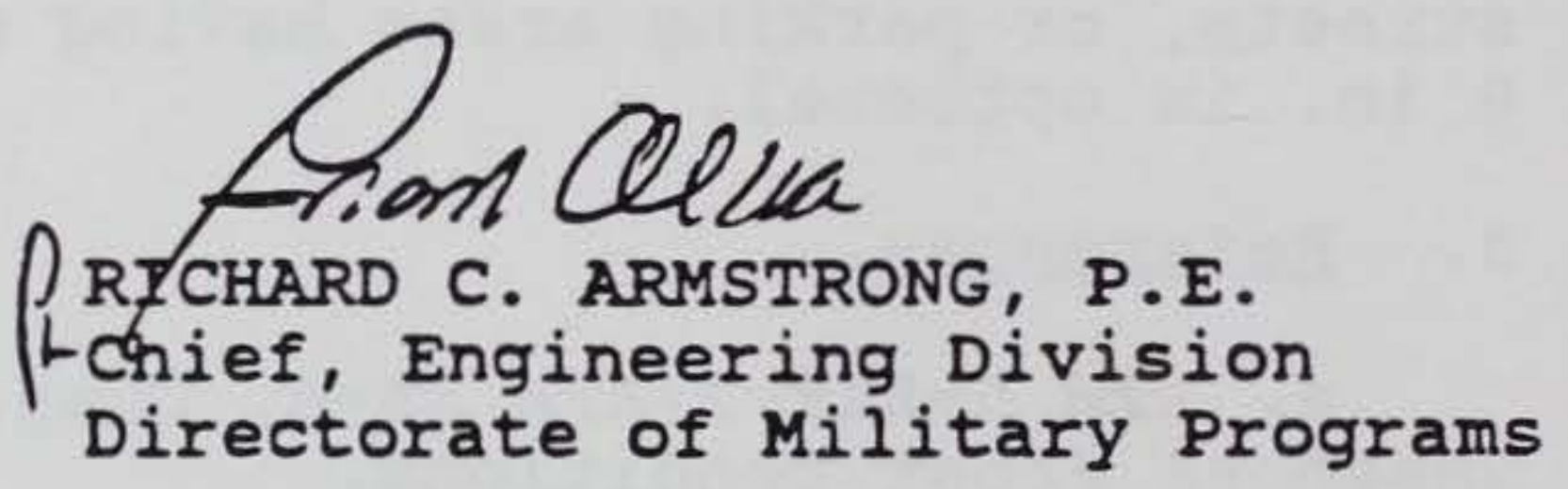




\section{TECHNICAL GUIDANCE FOR DESIGN OF THE SUBSURFACE DRAINAGE FOR MILITARY PAVEMENTS}

1. Introduction. Except in frost areas, the current design criteria for military pavements, as given in TM 5-822-5/AFM 88-7, Chap. 3; TM 5-822-2/ AFM 88-7, Chap. 5; TM 5-825-3/AFM 88-6, Chap 3; and TM 5-825-2/AFM 88-6, Chap. 2, are based on the assumption that the base and subbase layers will be adequately drained, 1.e., the criteria do not consider damage because of free water at layer interfaces nor for a loss of material strength caused by pore pressures induced by traffic. To ensure adequate subsurface drainage, major changes to the criteria for design of subsurface facilities (TM 5-820-2/ AFM 88-5, Chap. 2 and TM 5-818-2/AFM 88-6, Chap. 4) are being implemented. The chinges involve modifying the gradation for base materials, requiring a drainage layer for most pavements, adding procedures for design of the drainage layers, limiting the time for drainage of the base, and supersedes the guidance in TM 5-818-2/AFM 88-6 for a tree draining base in frost areas.

\section{Definitions.}

a. Drainage Layer. A drainage layer is a layer in the pavement structure that is specifically designed to allow horizontal drainage of water from the pavement structure. The layer is also considered to be a structural component of the pavement and will serve as part of the base or subbase. The drainage layer will consist of either a rapid draining material or an open graded material and will be designed by criteria provided in this Engineer Technical Letter(ETL).

\section{b. Separation Layer. A separation layer is a layer provided directly} beneath the drainage layer to prevent fines from infiltrating or pumping into the drainage layer and to provide a working platform for construction and compaction of the drainage layer. Generally, a minimum of $4 \mathrm{in}$. of densegraded aggregate material is used; however, a filter fabric can be used. The material for the granular separation layer should meet the requirements for a 50 CBR subbase as given in TM 5-822-5/AFM 88-7, Chap. 3 and TM 5-825-2/ AFM 88-6, Chap. 2. The requirements for filter fabric are given in TM 5-820-2/AFM 88-5, Chap. 2 .

c. Rapid Draining Material (RDM). A rapid draining material is a material having a sufficiently high permeability ( 1,000 to $5,000 \mathrm{ft} /$ day) to serve as a drainage layer and will also have the stability to support construction equipment and the structural strength to serve as a base and/or a subbase. Gradation limits for the RDM are given in Table 1, and the design properties are given in Table 2. To ensure adequate stability and strength, the uniformity coefficient $\left(C_{v}\right)$ of the RDM should be greater than 3.5 .

d. Open Graded Material (OGM). An open graded material is a material having a very high permeability (greater than 5,000 ft/day) which may be used for a drainage layer. Such a material will normally require stabilization for construction stability or for structural strength to serve as a base in a 
ETL $1110-3-435$

1 May 92

flexible pavement. Gradation limits for the OGM are given in Table 1, and the design properties are given in Table 2.

Table 1

Gradations of Materials for Drainage Layers and Choke Stone

\begin{tabular}{|c|c|c|c|}
\hline \multicolumn{3}{|c|}{ Drainage Layer Material } & \multirow[b]{2}{*}{ Choke Stone } \\
\hline $\begin{array}{c}\text { Sieve } \\
\text { Designation }\end{array}$ & $\begin{array}{c}\text { Rapid Draining } \\
\text { Material }\end{array}$ & $\begin{array}{l}\text { Open Graded } \\
\text { Material }\end{array}$ & \\
\hline $\begin{aligned} & 1-1 / 2 \text { in. } \\
& 1 \text { in. } \\
& 3 / 4 \text { in. } \\
& 1 / 2 \text { in. } \\
& 3 / 8 \text { in. } \\
& \text { No. } 4 \\
& \text { No. } 8 \\
& \text { No. } 16\end{aligned}$ & $\begin{array}{r}100 \\
70-100 \\
55-100 \\
40-80 \\
30-65 \\
10-50 \\
0-25 \\
0-5\end{array}$ & $\begin{array}{c}100 \\
95-100 \\
\cdots \\
25-80 \\
\cdots \\
0-10 \\
0-5 \\
\cdots\end{array}$ & $\begin{array}{r}100 \\
100 \\
100 \\
100 \\
80-100 \\
10-100 \\
5-40 \\
0-10\end{array}$ \\
\hline
\end{tabular}

Table 2

Properties of Materials for Drainage Layers

\begin{tabular}{|c|c|c|}
\hline Property & $\begin{array}{c}\text { Rapid Draining } \\
\text { Material }\end{array}$ & $\begin{array}{l}\text { Open Graded } \\
\text { Material }\end{array}$ \\
\hline $\begin{array}{l}\text { Permeability } \\
\text { ft/day }\end{array}$ & $1,000-5,000$ & $>5,000$ \\
\hline Effective Porosity & 0.25 & 0.32 \\
\hline Percent Fractured & 908 for $80 \mathrm{CBR}$ & 908 for $80 \mathrm{CBR}$ \\
\hline Faces (COE method) & 758 for $50 \mathrm{CBR}$ & 758 for $50 \mathrm{CBR}$ \\
\hline$c_{v}$ & $>3.5$ & $\cdots$ \\
\hline LA Abrasion & $<40$ & $<40$ \\
\hline
\end{tabular}

Note: $C_{v}$ is the uniformity coefficient $-D_{60} / D_{10}$. 
e. Choke Stone. A choke stone is a small size stone used to stabilize the surface of an OGM. The choke stone should be a hard, durable, crushed aggregate having 90 percent fractured faces. The ratio of $D_{13}$ of the coarse aggregate to the $D_{15}$ of the choke stone must be less than 5 , and the ratio of the $D_{50}$ of the coarse aggregate to $D_{50}$ of the choke stone must be greater than 2. The gradation range for acceptable choke stone is given in Table 1. Meeting the requirements of a choke stone would be either the ASTM No. 8 or ASSHO No. 9 stone.

f. Coefficient of Permeability. The coefficient of permeability is a measure of the rate at which water passes through unit area of material in a given amount of time under a unit hydraulic gradient.

g. Effective Porosity. The effective porosity is defined as the ratio of the volume of voids that will drain under the influence of gravity to the total volume of a unit of aggregate. The difference between the porosity and the effective porosity is the amount of water that will be held by the aggregate. For materials such as the RDM and OGM, the water held by the aggregate will be small; thus, the difference between the porosity and effective porosity will be small (less than 10 percent). The effective porosity may be estimated by computing the porosity from the unit dry weight of the aggregate and the specific gravity of the solids which then should be reduced by 5 percent to allow for water retention on the aggregate.

h. Stabilization. Unless experience indicates otherwise, stabilization of $O G M$ is required for stability and strength, and for preventing degradation of the aggregate in handling and compaction. Stabilization may be accomplished mechanically by use of a choke stone or by the use of a binder such as asphalt or cement. The choke stone will be used only with the OGM and will be referred to as a choked OGM. The asphalt or cement may be used with the OGM and will be referred to as an asphalt or cement stabilized OGM. Stabilization of the OGM is accomplished by using only enough asphalt or cement paste required to coat the aggregate. Care should be taken so that the voids are not filled by excess stabilizer. The stabilization material predominantly used is asphalt cement (AC-20) at 2 to $2-1 / 2$ percent (by weight) for the OGM. Higher asphalt cement percentages are required when a less open graded material is used. For example, New Jersey's asphalt cement stabilized permeable base gradation requires 3 percent asphalt cement to coat the aggregates. For additional asphalt stabilized permeable base stability, a stiffer asphalt cement, such as an AC-40, should be used. Portland cement at $1-1 / 2$ to $3 \mathrm{bags} / \mathrm{cu}$ yd has also been used. As with asphalt cement stabilized permeable base, the amount of portland cement per cubic yard will depend on the voids and surface area of the aggregate in the permeable material. For example, California uses not less than 282 lb of portland cement per cubic yard with a water-cement ratio of 0.37 . The permeability of this material is approximately 4,000 ft/day. Whereas, Wisconsin with a more open material (permeability approximately 10,000 ft/day) has found that $200 \mathrm{lb}$ of portland cement per cubic yard and a water-cement ratio of 0.37 provide adequate strength, durability, and stability. 
1. Degree of prainage. The degree of drainage is the ratio of water that has drained from a material to total amount of water that the aterial is capable of holding.

\section{Drainage Criteria.}

a. Concepts. For pavements in nonfrost areas and having a subgrade with a permeability greater than $20 \mathrm{ft} /$ day, one can assume that the vertical drainage will be sufficient such that no drainage layer is required. Also, flexible pavements in nonfrost areas and having a total thickness of $8 \mathrm{in}$. or less are not required to have a drainage layer. For pavements requiring drainage layers, the design of the drainage layer shall be based on the premise that the capacity of the drainage layer should be greater than the volume of water entering the pavement, and that the drainage layer, if saturated, should reach a degree of drainage of 0.85 within 1 day after the inflow of water stops. The degree of drainage for the drainage layer is defined as the volume of water that has drained from the layer over a specified time period divided by the total volume of water in the layer that can be drained by gravity.

b. Design Water Inflow. The subsurface drainage of the pavement is to be designed to handle water infiltration through the pavement from a design storm index for a design storm of $1 \mathrm{hr}$ duration at an expected return frequency of 2 years. For the continental United States, this can be determined from Figure 1 (taken from TM 5-820-1/AFM 88-5, Chap. 1). Guidance for determining the design storm for other parts of the world is also given in TM 5-820-1/

AFM 88-5, Chap. 1. The inflow is determined by multiplying the design rainfall index ( $R$ in inches per hour) times an infiltration coefficient $F$. This coefficient will vary over the life of the pavement depending on the type of pavement, sprface drainage, pavement maintenance, and structural condition of the pavement. Since the determination of a precise value of the infiltration for a particular pavement is very difficult, a value of 0.5 may be assumed for design. The value of the coefficient may be changed based on local experience and anticipated inflow rates for a particular pavement. The rate of water inflow ( $q$ in cubic feet per foot width of drainage path per hour) is then computed by the equation

$$
q=L \times F \times(R / 12)
$$

where

$L$ - length of the drainage path in feet

F - infiltration coefficient

$R$ - design rainfall index in inches per hour

It should be noted that the drainage layer design is based only on the infiltration of water from the surface. Normally, other sources would provide 
ETL $1110-3-435$

1 May 92

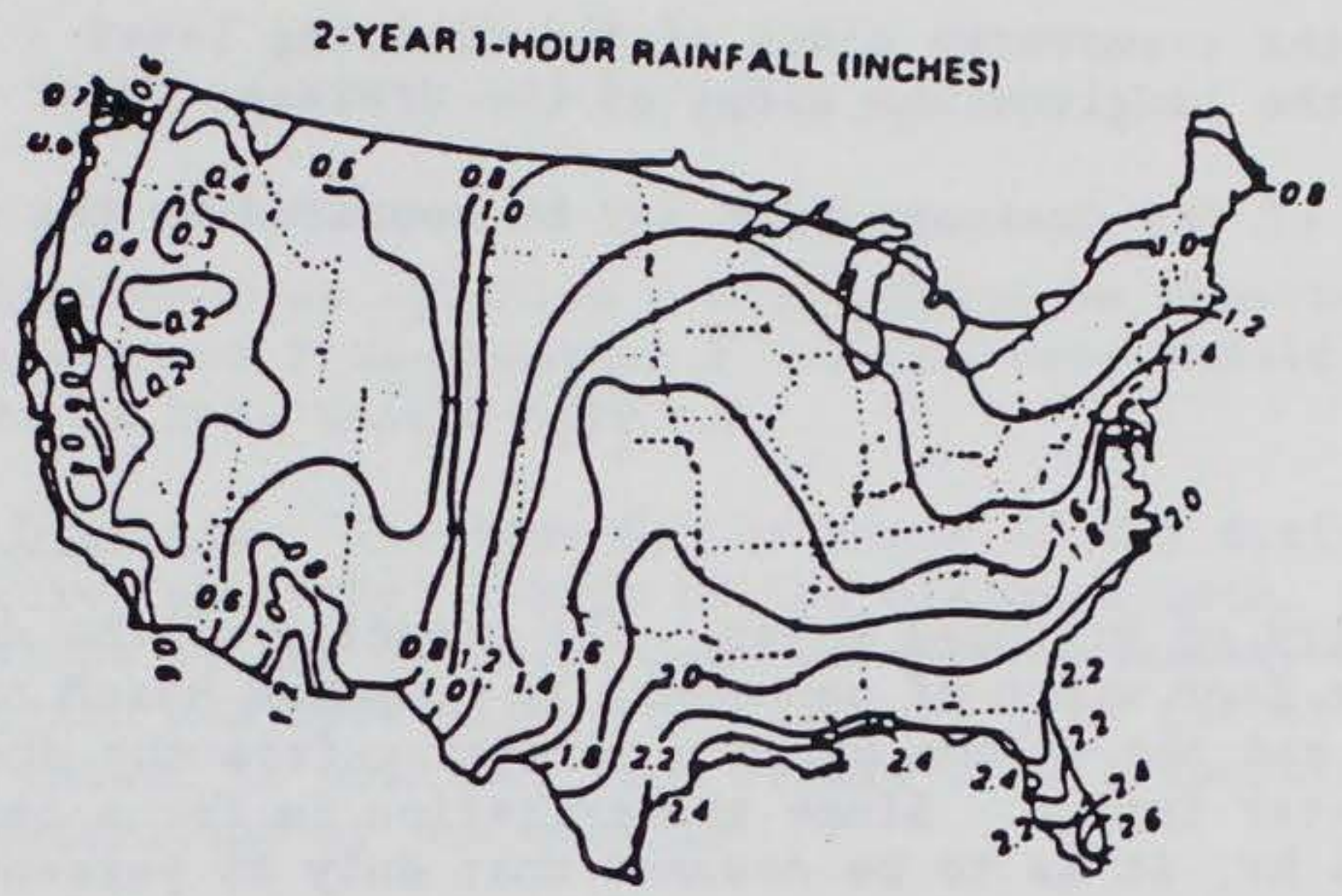

Figure 1. Design Storm Index, 1-hr Rainfall Intensity-Frequency Data for Continental United States Excluding Alaska (Chart reproduced from US Weather Bureau, Technical Paper No. 40, Rainfall Frequency Atlas of The United States, Washington, DC, May 1961.)

water to the drainage layer but such water would be minor and would not be a consideration in the design of the drainage layer. Should ground water be present in any substantial quantities, special provisions should be made to intercept and drain the water before it reaches the drainage layer. The drainage layer is expected to aid in draining of water in the subbase and subgrade caused by frost action, but this volume of water will not be considered in computing the design water inflow.

c. Length and Slope of Drainage Path. The length of drainage path is measured along the slope of the drainage layer from the crest of the slope to where the water will exit the drainage layer. In simple terms, the length of the drainage path is the maximum distance water will travel in the drainage layer. The length of drainage path ( $L$ ) in feet may be computed by the equation

$$
L=\frac{X \sqrt{i_{t}^{2}+i_{0}^{2}}}{i_{t}}
$$

where

$X$ - the length in feet of the transverse slope of the drainage layer 
ETL $1110-3-435$

1 May 92

$1_{t}$ - the transverse slope of the draining layer

1 . - the longitudinal slope of the drainage layer

The slope (1) of the drainage path may be computed by the equation

$$
1=\sqrt{i_{t}^{2}+1^{2}}
$$

d. Capacity of Drainage Layer. The capacity of the drainage layer ( $Q$ in cubic feet per foot width of pavement) is computed based on the effective porosity $\left(n_{0}\right)$ and the volume of water draining from the drainage layer during the $1 \mathrm{hr}$ of water inflow. Since the criterion is for a degree of drainage of 0.85 within $24 \mathrm{hr}$, it is to be assumed that only 85 percent of the voids will be available for storage of water. Thus, the capacity of the drainage layer may be computed by the equation

$$
Q=(0.85)\left(n_{0}\right)(H)(L)+(k / 24)(t)(i)(H) / 2
$$

where

$$
\begin{aligned}
& Q \text { - capacity of the drainage layer in cubic feet/feet } \\
& n_{0} \text { - effective porosity } \\
& H \text { - thickness of the drainage layer in feet } \\
& \text { - length of the drainage path in feet } \\
& k \text { - permeability of the drainage layer in feet/day } \\
& t \text { - } 1 \text { hr (length of design storm) } \\
& i \text { - slope of the drainage path in feet/foot }
\end{aligned}
$$

e. Thickness of Drainage Layer. By setting $Q-q$ and substituting equations 1 and 4 for $q$ and $Q$, the minimum thickness in feet of the drainage layer required to provide the storage capacity for a 1 hour design storm is determined from the equation

$$
\mathrm{H}=4 \mathrm{FRL} /\left[40.8 \mathrm{n}_{\bullet} \mathrm{L}+\mathrm{ki}\right]
$$

If the term (ki) is small compared to the term $\left(40.8 n_{0} L\right)$ which would probably be the case for long drainage paths ( $>20 \mathrm{ft}$ ), then the required thickness of the drainage layer can be estimated by deleting the term (ki) from equation 5 or 
ETL $1110-3-435$

$$
H=(F R) /\left(10.2 n_{\bullet}\right)
$$

The value of $\mathrm{H}$ obtained from equation 6 will always be somewhat greater than the value of $H$ deternined from equation 5 . In no case should the thickness of the drainage layer be less than $4 \mathrm{in}$.

f. Time for Drainage. The time for drainage of the drainage layer is a function of effective porosity, length of the drainage path, thickness of the drainage layer, slope of the drainage path, and permeability of the drainage layer. This function has been solved in terms of time factor IF and a parameter m. The time factor is obtained from Figure 2 as a function of the parameter $s$ which is determined by the equation

$$
s=\mathrm{LI} /(\mathrm{H})
$$

After determining the time factor TF from Figure 2, the time required to obtain a degree of drainage of 0.85 is computed from

$$
T_{85}=(T F)(m)
$$

where

$T_{85}$ - time in days required to obtain a degree of drainage of 0.85

$m$ - a parameter defined as

$$
\left(\mathrm{n}_{0} \mathrm{~L}^{2}\right) /(\mathrm{KH})
$$

g. Design Example. Assume the following design parameters are appropriate for a large parking lot.

The design rainfall (R) -2.0 in.

The effective porosity $\left(n_{0}\right)-0.2$

The length of the drainage path (L) $-150 \mathrm{ft}$

The permeability of the drainage material (k) $-2,000 \mathrm{ft} /$ day 
ETL $1110-3-435$

1 May 92

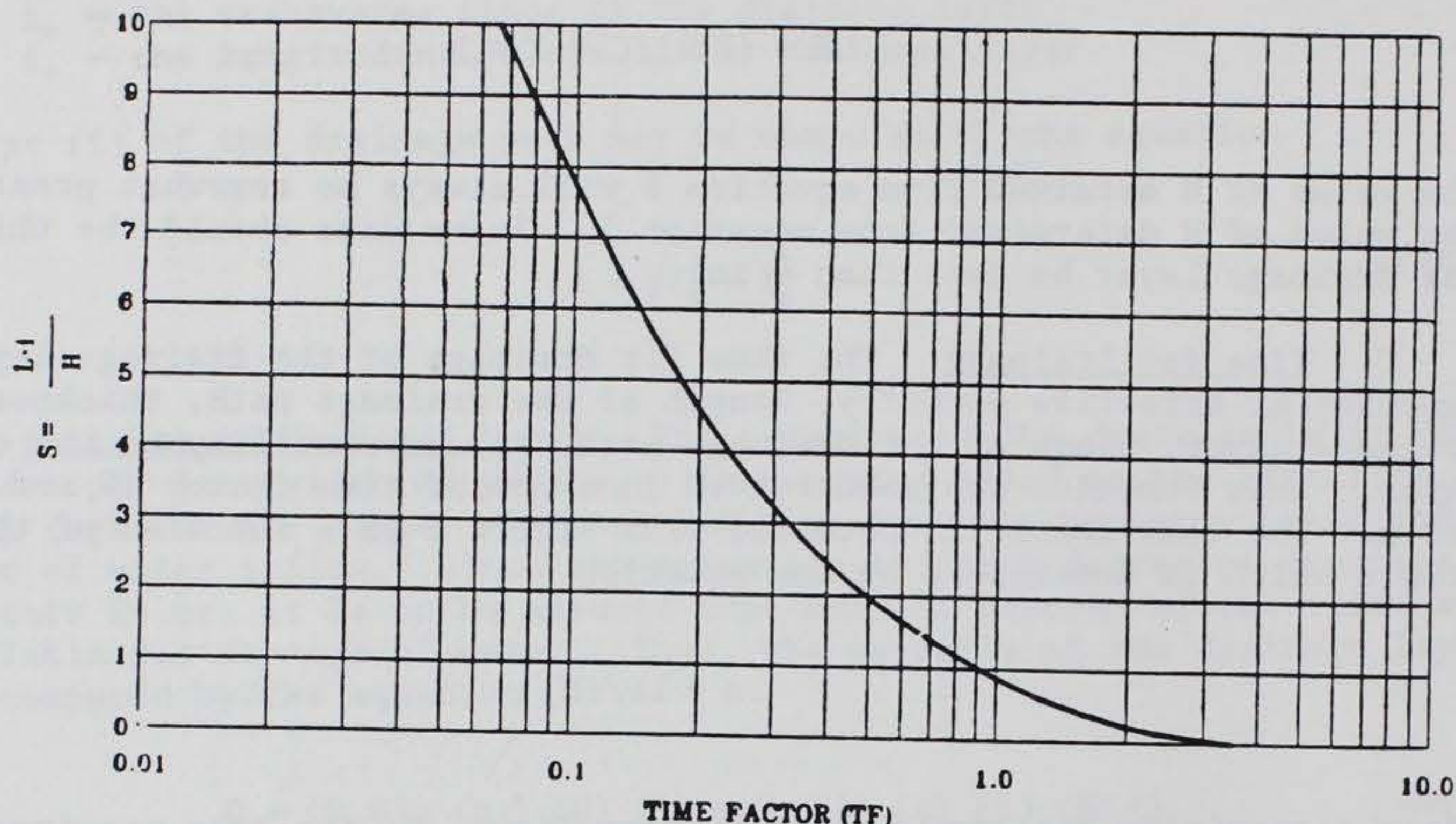

Figure 2. Time Factor for 85 Percent Drainage

The slope of the drainage path (1) $=0.01$

The infiltration coefficient $(F)=0.5$

First the thickness, $H$, of the drainage layer required to provide the necessary storage capacity is computed by substituting into equation 5 as follows

$$
\begin{gathered}
H=[4(0.5)(2.0)(150)] /[40.8(0.2)(150)+(0.01)(2,000)] \\
H=0.48 \mathrm{ft} . \text { or } 5.8 \mathrm{in.}
\end{gathered}
$$

Rounding the computed thickness up to the next full inch gives a design thickness of 6 in. Equation 6 could have been used to estimate the thickness as follows

$$
H=F R / 10.2 n_{0}-[(0.5)(2)] /[(10.2)(0.2)]-0.49 f t
$$

Again the thickness would round up to 6 in. The next step would be to use Figure 2 to determine the time to obtain a degree of drainage of 0.85 . Using equation 7 the value of $s$ is computed to be 3.0 and from equation 9 the value of $m$ is computed to be 4.5. From Figure 2 the time factor, $T F$, is found to be 0.32 . The time to obtain a degree of drainage of 0.85 is computed from equation 8 .

$$
T_{85}=(T F)(m)-(0.32)(4.5)=1.44 \text { days }
$$


Since 1.44 days is considerably greater than the 1 day allowed by the criteria, the design must be modified to obtain a shorter time for drainage. The parameter that can be changed will depend on the particular design situation but for this example assume the design can be modified to obtain a drainage path of $100 \mathrm{ft}$. The thickness required for storage is found from equation 5 to be $6 \mathrm{in}$. The $s$ parameter for entering Figure 2 is now 2.0 which gives a time factor, $T F$, of 0.5 . The m parameter is computed from equation 8 to be 2.0. Equation 7 is again used to compute $T_{85}$.

$$
T_{85}=(T F)(m)-(0.5)(2.0)-1 \text { day }
$$

The 1 day required for drainage meets the criteria; thus, the design would call for a 6-in. drainage layer with a 100-ft drainage path.

\section{Placement.}

a. Rigid Pavements. In the case of rigid pavements the drainage layer, if required, shall be placed as shown in Figure $3 a$ directly beneath the concrete slab. In the structural design of the concrete slab the drainage layer along with any granular separation layer shall be considered a base layer, and structural benefit may be realized from the layers. -

b. Flexible Pavements. In the case of flexible pavements the drainage layer should be placed either directly beneath the surface layer as shown in Figure $3 a$ or beneath a graded crushed aggregate base course as shown in Figure $3 \mathrm{~b}$. If the thickness of granular subbase is equal to or greater than the thickness of the drainage layer plus the thickness of the separation layer, the drainage layer is placed beneath the graded crushed aggregate base (Figure $3 \mathrm{~b}$ ). Where the total thickness pavement structure is less than 12 in., the drainage layer may be placed directly beneath the surface layer (Figure $3 a$ ) and the drainage layer would serve as the base. When a graded crushed aggregate base is used above the drainage layer, care must be taken to limit the material passing the No. 200 sieve in the graded crushed aggregate base to 8 percent or less. These precautions are necessary to provide adequate drainage and to ensure that an excess of fines will not be available to wash into the drainage layer. Should a graded aggregate base not be available, then it is suggested that an asphalt stabilized base be used above the drainage layer. In areas where frost will penetrate the base, the base must also meet the criteria in TM 5-818-2/AFM 88-6, Chap. 4 for a nonfrost susceptible material.

5. Separation Layer. The drainage layer must be protected from contamination of fines from the underlying layers by a separation layer to be placed directly beneath the drainage layer. In most cases the separation layer should be a graded aggregate material meeting the requirements of a 50 CBR subbase. The minimum thickness for the separation layer is 4 in. A granular separation layer provides a firm foundation for compaction of the drainage layer and adds strength to the pavement structure. For design situations where a firm foundation already exists and the thickness of the separation layer is not needed in the structure for protection of the subgrade, a filter 
ETL 1110-3-435

1 May 92

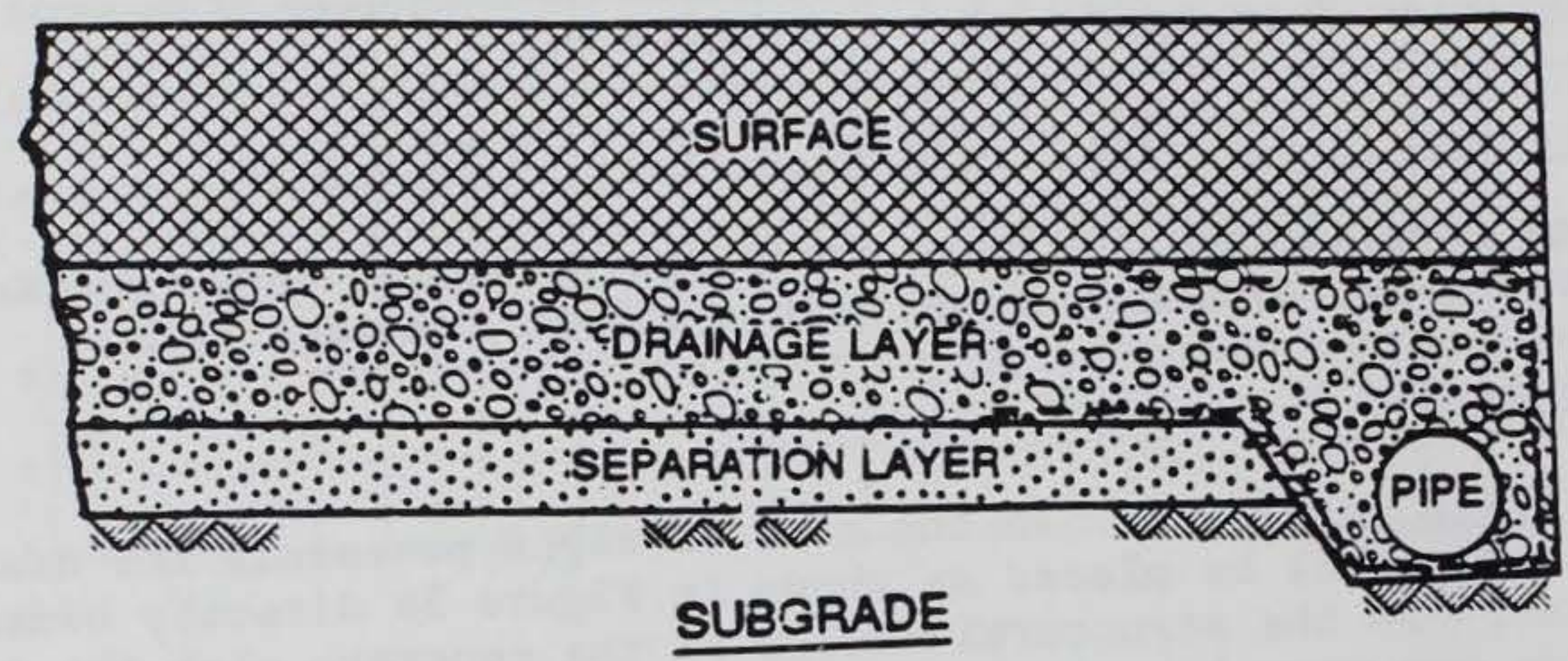

3a. Placed Under Surface

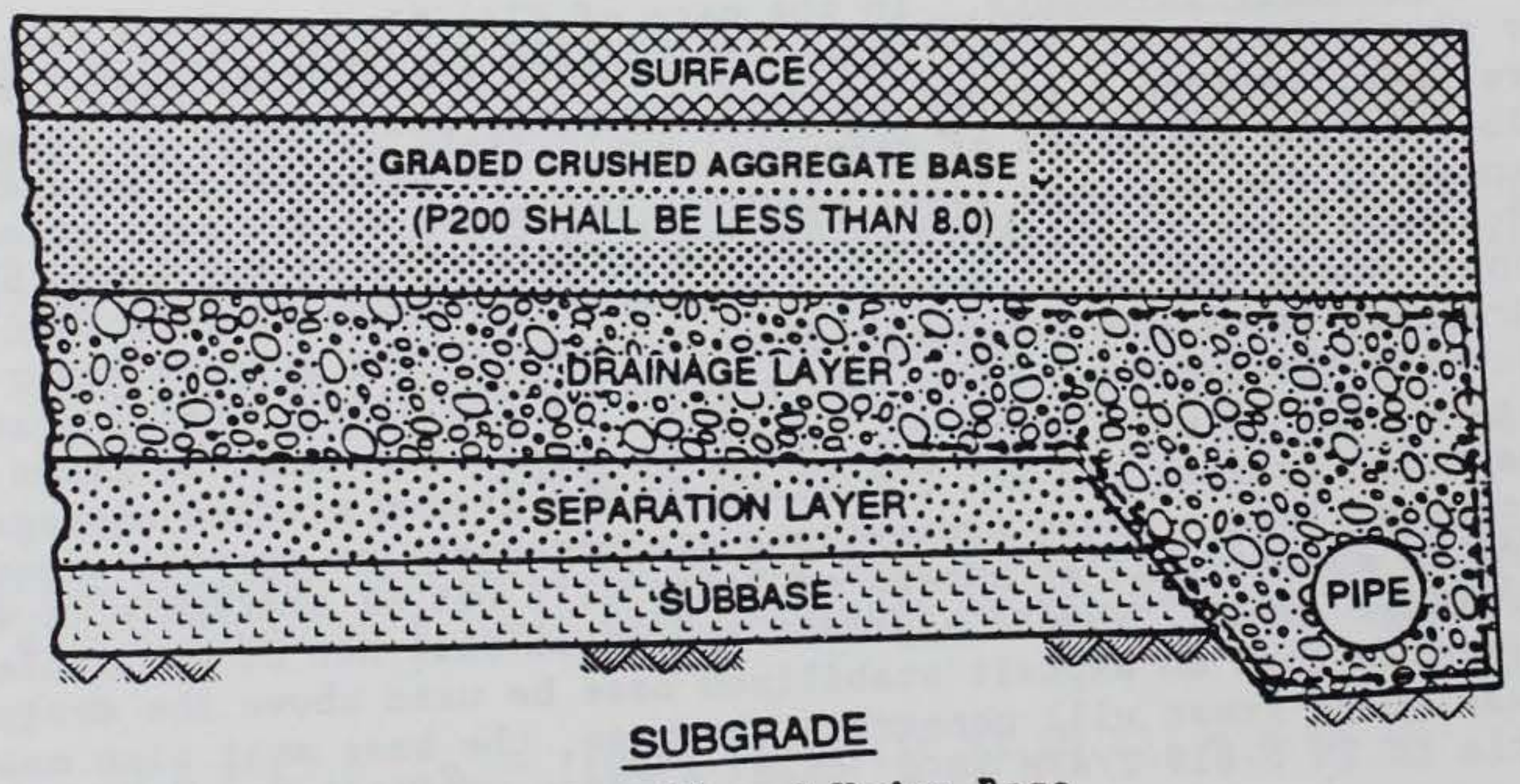

3b. Placed Under Base

Figure 3. Drainage Layer Placement 
fabric may be substituted for the granular separation layer. The fabric must meet the requirements specified in TM 5-820-2/AFM 88-5, Chap. 2.

\section{Material Properties.}

a. Strength and Durability. The material for a drainage layer should be a hard, durable crushed aggregate. Crushed aggregate meeting the gradation requirements of the RDM will provide sufficient stability for the drainage layer on which construction equipment such as dump trucks, transit trucks, and tracked pavers can operate.

b. Material Permeability. The permeability of the drainage layer is primarily a function of the material gradation and density. For a given gradation, it is important for strength considerations to obtain the maximum possible density during compaction without crushing the aggregate. Thus, the permeability is controlled by controlling the gradation. Table 2 provides estimates for the permeability of RDM and OGM that are applicable to the gradation of the in-place material. The e should be very few design situations requiring drainage materials having permeabilities greater than $5,000 \mathrm{ft} /$ day; thus, the OGM will almost always meet the permeability requirements. For RDM, a permeebility of $2,000 \mathrm{ft} /$ day may be used for design. If the required permeability is between 2000-5000 ft/day the RDM may be used provided the RDM is restructured to the coarse side of the gradation band. This value or laboratory determined permeability value may be used as estimates of the in-place permeabilities until local experience with construction of drainage layers can establish the in-place permeabilities being obtained.

\section{Construction.}

a. Experience. Without properly trained personnel, construction of the drainage layer can cause problems. Experience with highly permeable bases (drainage layers) both by the Corps of Engineers and various State Departments of Transportation indicates that pavements containing such layers can be constructed without undue difficulties provided certain guidelines are followed. These guidelines are discussed below.

b. Placement. The material for the drainage layer must be placed in a manner to prevent segregation and to obtain a layer of uniform thickness. The materials for the drainage layer will require extra care in stockpiling and handling. Placement of the RDM and OGM is best accomplished using an asphalt concrete paver. To ensure good compaction, the maximum lift thickness should be no greater than $6 \mathrm{in.}$. If choke stone is used to stabilize the surface of $O G M$, the choke stone is placed after compaction of the final lift of OGM. The choke stone is spread in a thin layer no thicker than $1 / 2$ in. using spreader box or paver. The choke stone is worked into the surface of the OGM by the use of a vibrator roller and by wetting. The choke stone remaining on the surface should not migrate into the OGM by the action of water or traffic. 
ETL $1110-3-435$

1 May 92

c. Proof Rolling. For Army Class IV and Air Force heavy, modified heavy, and medium load flexible aiffield pavements, proof rolling as per TM 5-825-2/ AFM 88-6 Chap. 2, is required on the graded crushed aggregate base even when used over a drainage layer. Proof rolling the separation layer prior to placement of the drainage layer for other pavements is recommended. For other Air Force flexible pavements and Army Class III flexible pavements, it is recommended that the proof rolling be accomplished using a rubber-tired roller with each tire loaded to $20,000 \mathrm{lb}$ or more and inflated to at least $90 \mathrm{lb} /$ sq in. A minimum of six coverages should be applied where a coverage is the application of one tire print over each point in the surface of the designated area. For rigid pavements and flexible pavements for roads, streets, parking lots and Class I and II Army airfields, proof rolling of the separation layer may be accomplished using the rubber-tired roller described above or by using a truck having tandem axles with either dual tires or super single tires. The truck should be loaded to provide 20,000 lb per axle. During proof rolling, action of the separation layer must be monitored for any sign of excessive movement or pumping that would indicate soft spots in the separation layer or the subgrade. Since the successful placement of the drainage layer depends on the stability of the separation layer, all weak spots must be removed and replaced with stable material. All replaced material must also be proof rolled as specified above.

d. Compaction. Compaction is a key element in the successful construction of the drainage layer. Compaction control normally used in pavement construction is not appropriate for materials such as the RDM and OGM. It is therefore, necessary to specify compaction techniques and level of effort instead of the properties of the end product. It will be important to place the drainage material in relatively thin lifts ( 6 in. or less) and to have a good firm foundation beneath the drainage material. The recommended method of determining the required compaction effort is to construct a test section and closely monitor the aggregate during compaction to determine when crushing of the aggregate appears excessive. Experience has indicated that sufficient compaction can be obtained by six passes or less of a 10-ton vibrator roller. Material not being stabilized with asphalt or cement should be kept moist during compaction. Asphalt stabilized materials for the drainage layer must be compacted at a somewhat lower temperature than a dense-graded asphalt material. In most cases it will be necessary to allow an asphalt stabilized material to cool to less than $200^{\circ} \mathrm{F}$ before compaction. After compaction, the drainage layer should be protected from contamination by fines from construction traffic or from flow of surface water. It is recommended that the surface layer be placed as soon as possible after placement of the drainage layer. Precautions must also be taken to protect the drainage layer from disturbance by construction equipment. Only tracked asphalt pavers should be allowed for paving over any RDM or OGM that has not been stabilized. Drivers should avoid rapid acceleration, hard braking, or sharp turning on the completed drainage layer. 
e. In-place Permeability. The permeability of an RDM can easily be reduced to an unacceptable level by over compaction or contamination with fines. The in-place RDM should easily accept the inflow of water without ponding or flowing across the surface. In-place permeability tests for materials as open as the RDM are difficult to run but may be conducted to get estimates of the in-place perneability. Laboratory permeability tests may be conducted, but care must be taken to ensure that the laboratory samples are representative of the in-place material. In laboratory tests the permeability is normally measured in the direction of compaction, whereas, in the drainage layer the water flow is perpendicular to the direction of compaction. If such is the case, the field permeability may be an order of magnitude higher than the laboratory permeability.

\section{Collector Drains.}

a. Design Flow. It is absolutely essential that all pavements having drainage layers be provided with collector systems as specified in TM 5-820-2/ AFM 88-5, Chap. 2, such that positive relief of water from the pavement will be provided. The collector system should have the capacity to handle the water from the drainage layer plus water from other sources. The volume of water entering the collector system from the drainage layer is computed assuming the drainage layer is flowing full. Thus, the volume of water (QO) in cubic feet per day per foot of length of collector (assuming the drainage layer is only on one side of the collector) would be

$$
\text { Q० }=\mathrm{H} \times \mathbf{i} \times \mathbf{k}
$$

where

$\mathrm{H}$ - thickness of the drainage layer in feet

$i$ - slope of the drainage layer in feet/feet

$k$ - permeability of the material in the drainage layer in feet/day

If the collector system has water entering from both sides, the volume of water entering the collector would be double that given by equation 10 .

b. Collector Pipe. The collector pipe may be perforated flexible, $A B S$, corrugated polyethylene or smooth rigid polyvinyl chloride pipe. The minimum size pipe that is to be used for a collector pipe is $6 \mathrm{in}$. and the mid height of the pipe is to be located a minimum of $12 \mathrm{in}$. below the separation layer. The backfill material around the collection pipe is to an OGM (or RDM provided the drain layer is RDM) and is to be protected from infiltration of fines by a filter fabric. In areas where frost is predicted to penetrate to the depth of the collector trench and differential heave would cause problems, the sides of the trench above the depth of frost penetration shall be sloped not steeper than 1 vertical on 10 horizontal. Typical details for 


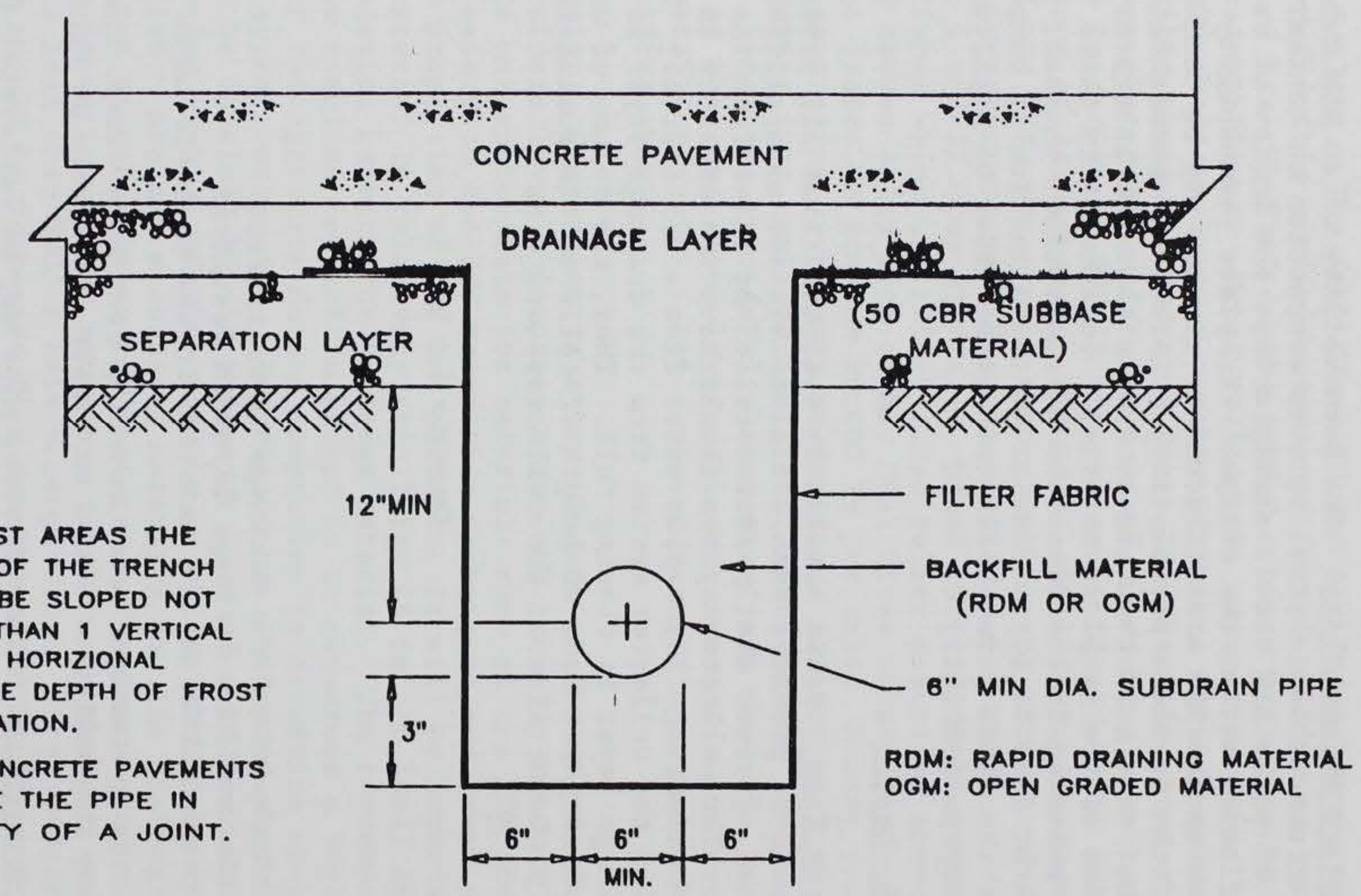

Figure 4. Typical Concrete Pavement Interior Subdrain Detall 


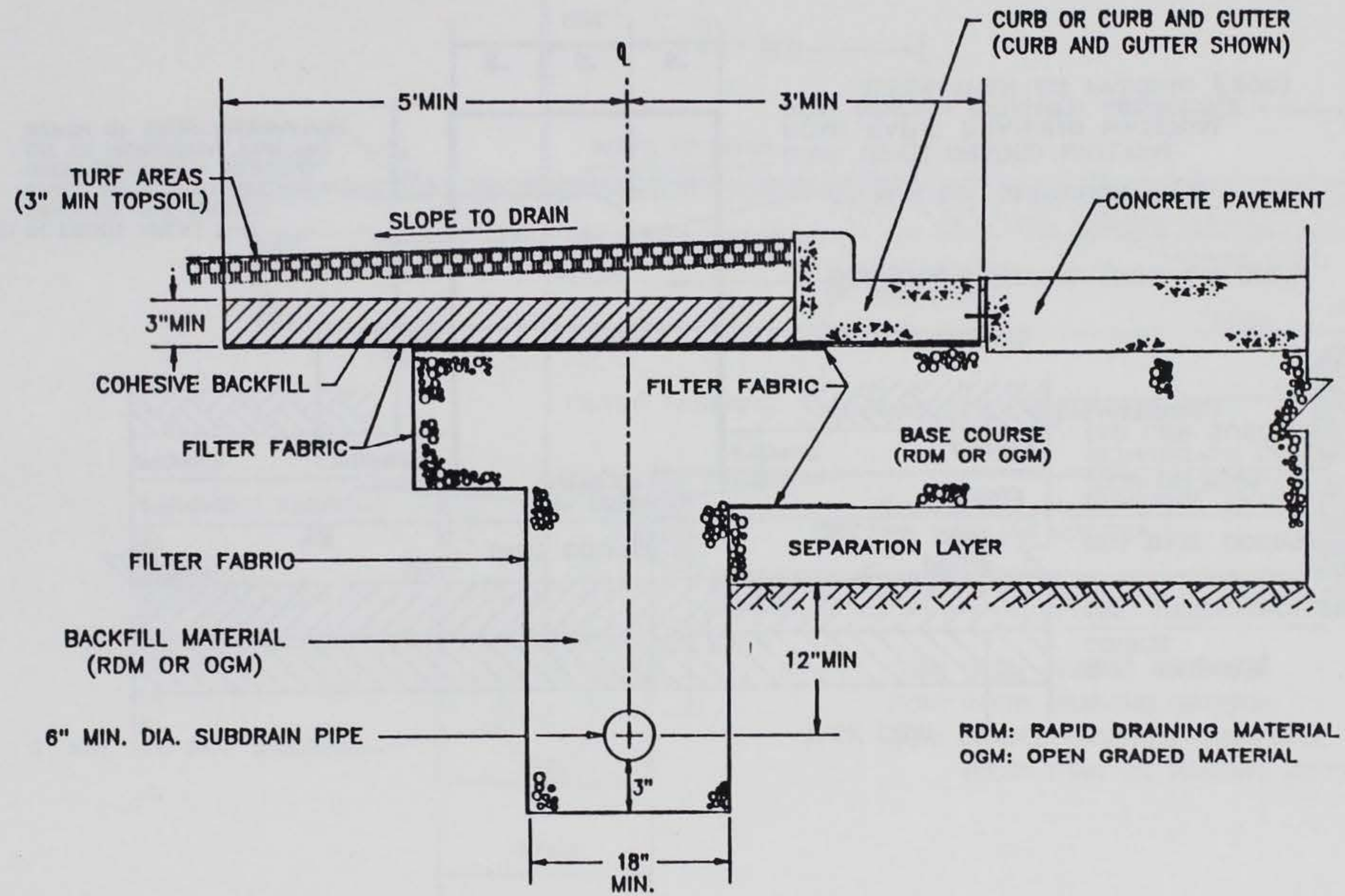

Figure 5. Pavement Edge Subdrain for Concrete Pavements 


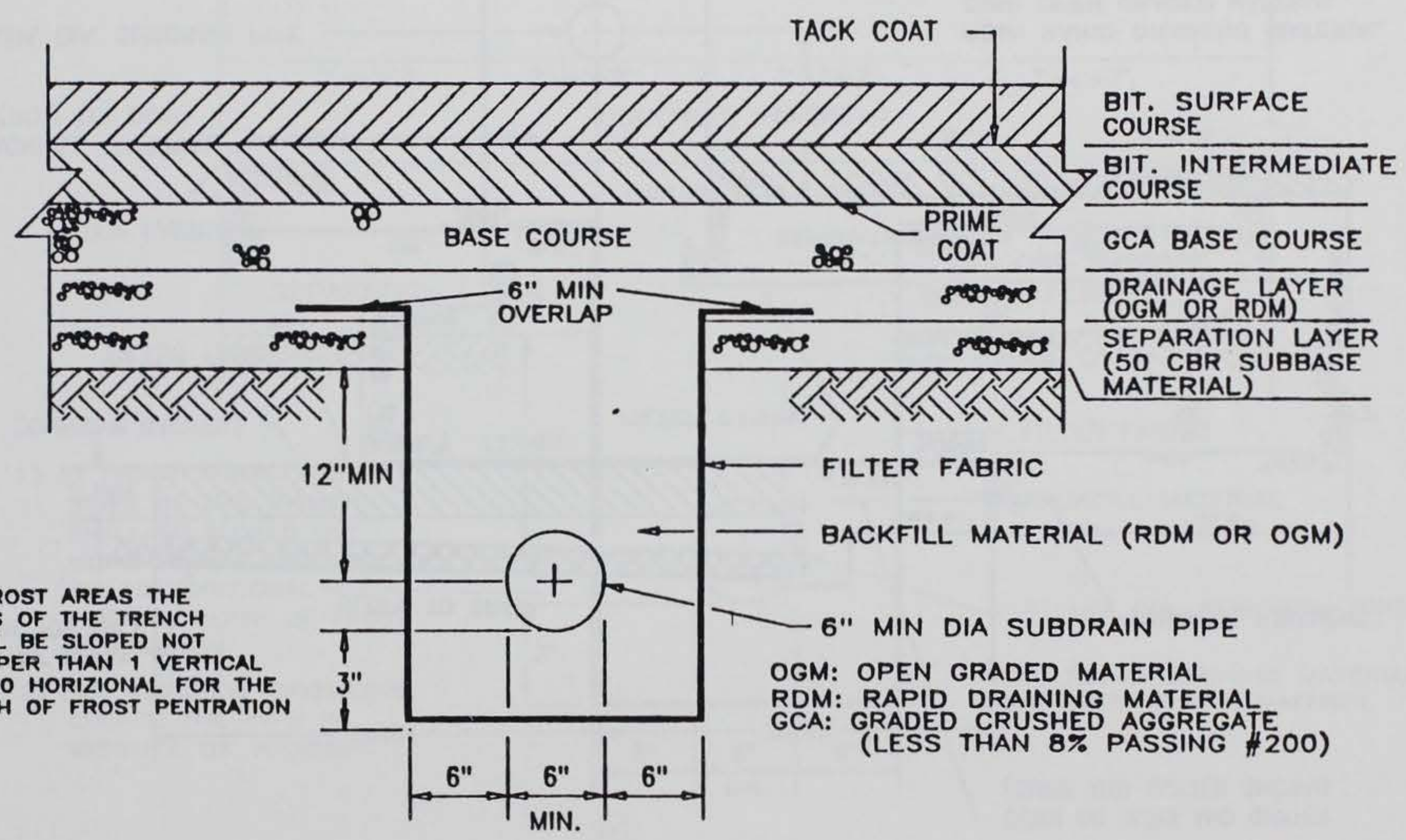

Figure 6. Typical Bituminous Pavement Interior Subdrain Detail 


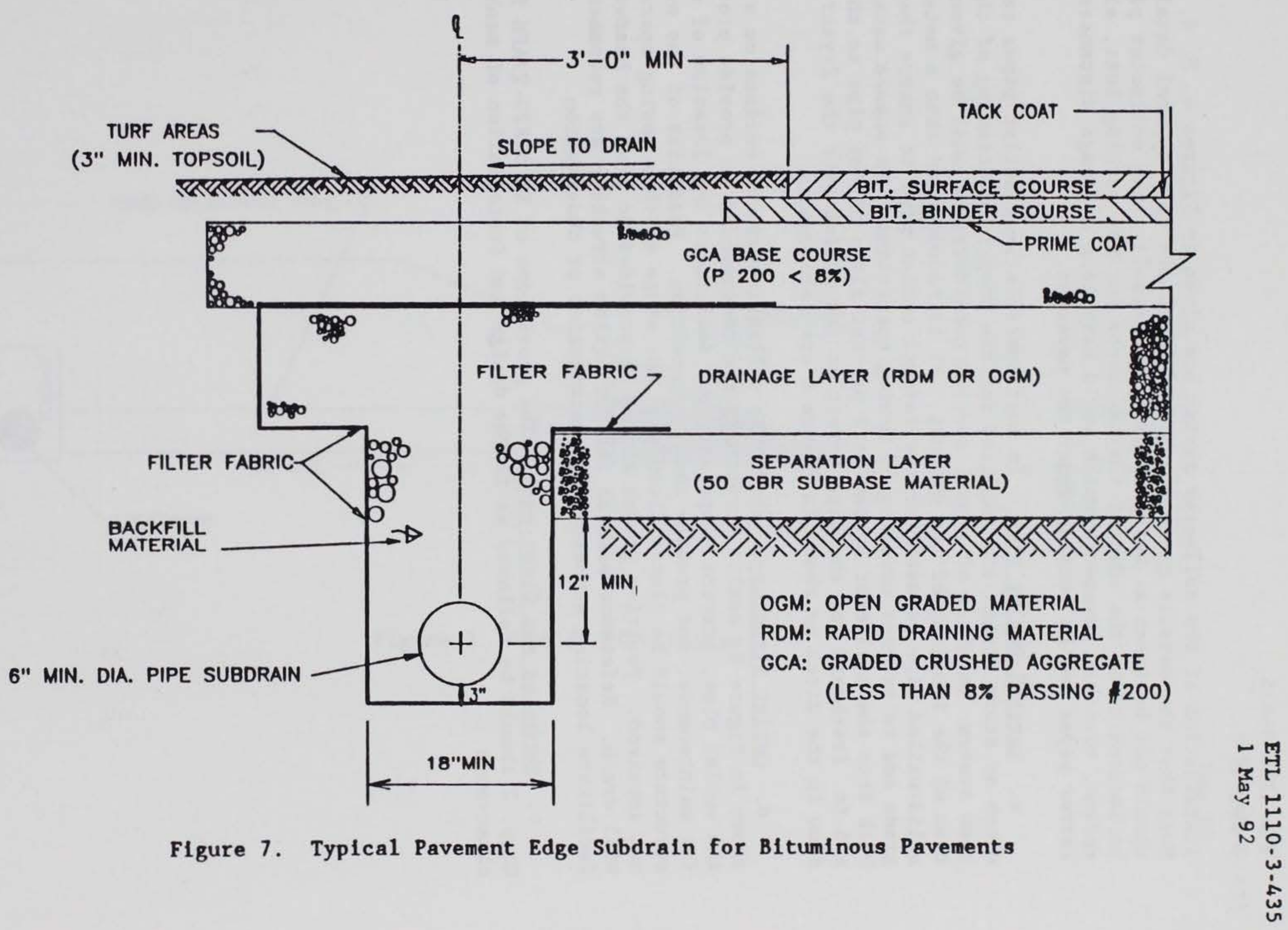


installation of the collector system are given in Figures $4,5,6$, and 7 . Note that the details given in these figures are only typical details and should not be taken as being mandatory. Normally, the collector pipes are to be located along the edge of the pavements but for parking lots, airfield aprons, or other pavements which would have long drainage distances the collector pipes may be located under the pavement.

c. Lateral outlet Pipe. In most installations outlet pipes to an open ditch or storm drains are required for the proper functioning of the collection system. In areas of frost, special consideration must be given to prevention of the freezing of the outlets. It is recommended that a metal or rigid solid-walled pipe be used for the lateral outlet pipe to ensure the proper grade and to prevent crushing by mowing operations. To ensure water does not back into the collector system, a 3 percent slope of the pipe to the ditch and a 6-in. freeboard for the pipe invert at the outlet over the 2-year design flow in the ditch as shown in Figure 8 are recommended.

d. Outlet Structure. Where the collection system outlets on a slope as shown in Figure 8, outlet structures are recommended to provide protection of the outlet pipe, prevent slope erosion, facilitate the location of outlet pipe for maintenance, and provide rodent protection. Headwalls of the outlet structure should be placed flush with the slope so that mowing operations are not impaired. Positive grades should be provided so that the headwall apron will drain. Reference markers for the outlet structure are recommended to facilitate locating structure for maintenance or observation.

e. Manholes and Clean-outs. The provisions of TM 5-820-2/AFM 88-5, Chap. 2 should be followed as to the design and installation of manholes and clean-outs. 


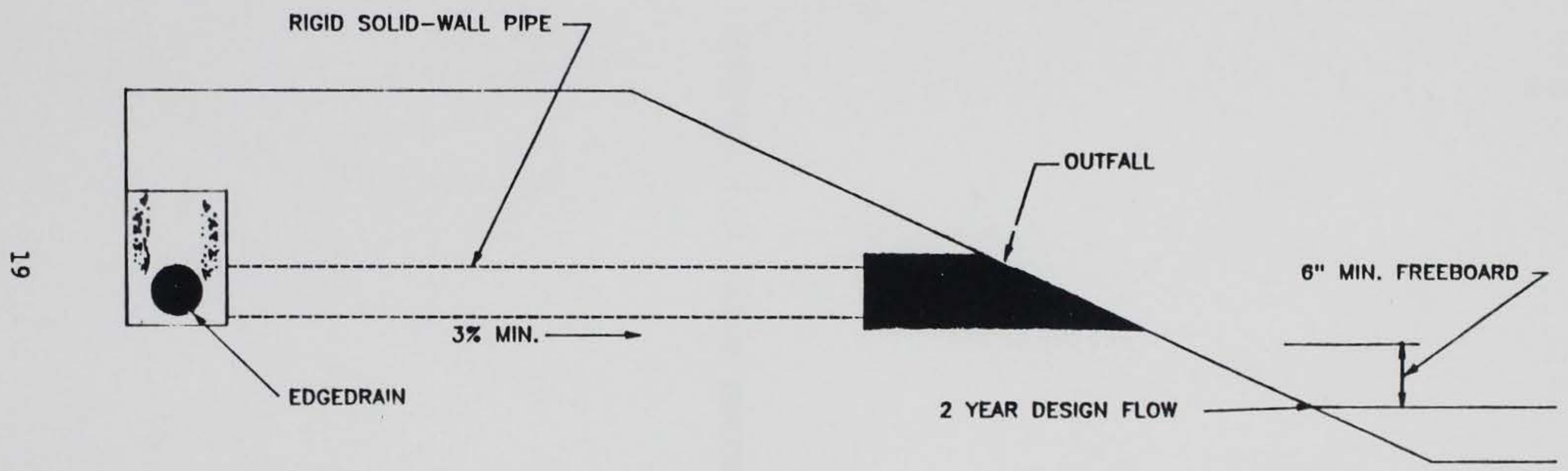

Figure 8. Outlet Plpe Design 
APPENDIX B: FACT SHEET 


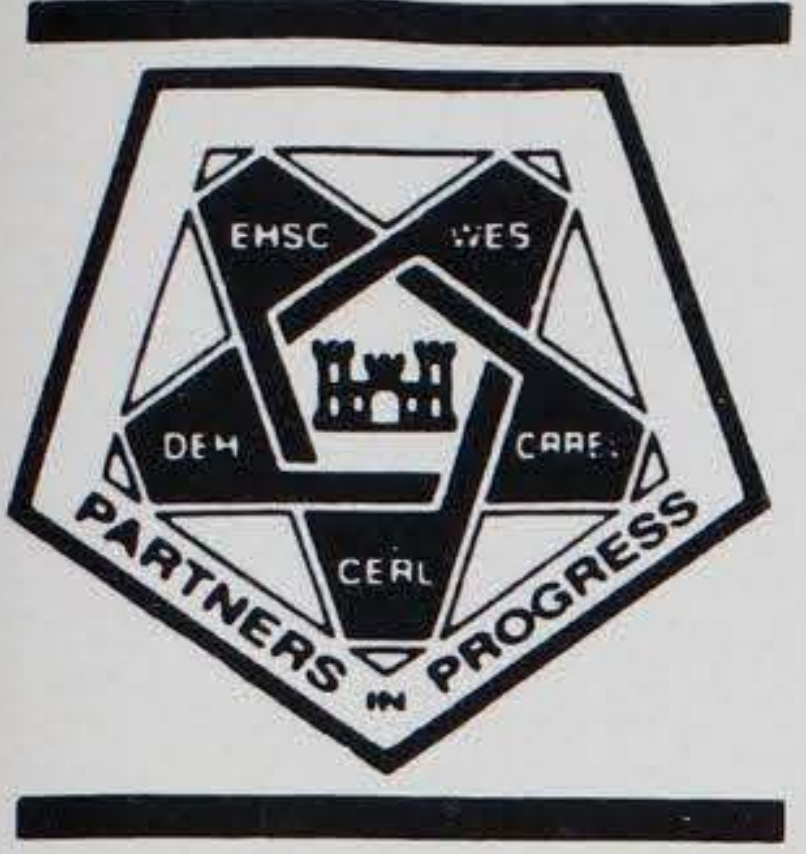

PRR-11

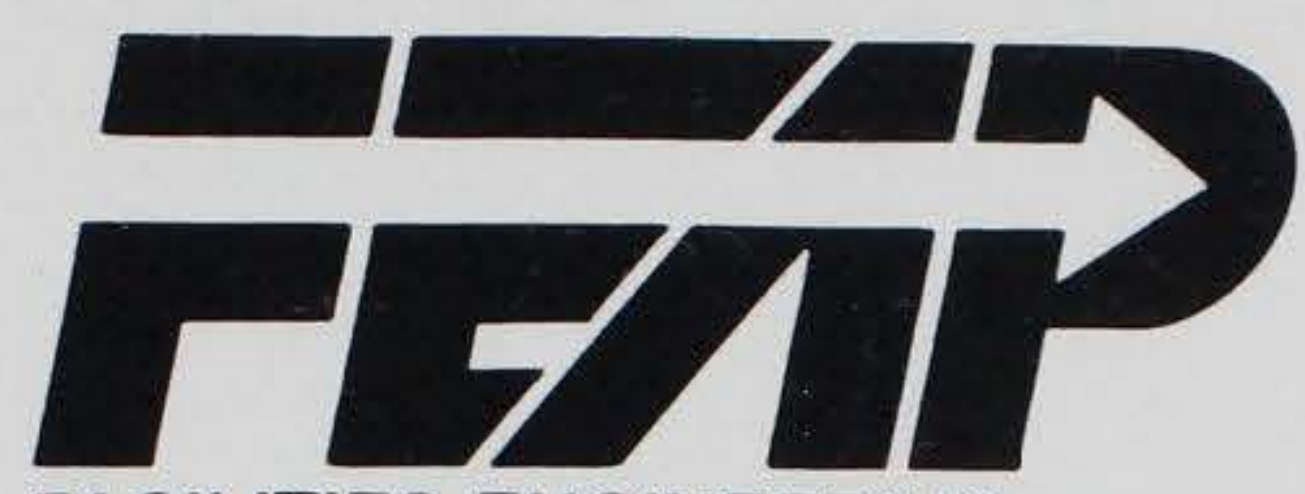

FACILITIES ENGINEERING APPLICATIONS PROGRAM
Egct Sheę

March 1990

\section{Pavement Drainage: Open-Graded Base}

Description of Technology

Status of Demonstration

Benefits of Technology

Points of Contact
The Corps of Engineers is committed to providing pavement design that ensures adequate subsurface drainage. The U.S. Army Engineer Waterways Experiment Station (WES) believes sufficient reason exists to change the current subsurface drainage criteria for military pavements. The changes WES is recommending will require drainage layers in all pavements except those having highly permeable subgrades. The time for drainage will be greatly reduced, requiring the use of open-graded bases. Such bases should have a minimum permeability of 1000 feet per day, be a good, durable crushed aggregate, and be placed on a firm subgrade or filter. Open-graded bases can be stabilized with asphalt or by choking as needed for strength and/or stability during construction.

The Corps' Ohio River Division has agreed to designate a pavement construction project in which an open-graded base will be used. The scheduling of the demonstration will depend on the project selected.

Poor pavement drainage has long been recognized as a major cause of premature pavement failure. Water in the pavement structure reduces strength of both the subgrade and base materials. By ensuring proper subsurface drainage, these early failures can be prevented. The result will be a more reliable, longer lasting pavement.

Walter R. Barker or Richard H. Grau, WES, 3909 Halls Ferry Road, Vicksburg, MS 39180-6199, COMM 601-634-3336, toll-free 800-522-6937, ext 3336. Ken Gregg, U.S. Army Engineering and Housing Support Center, COMM 703-355-3582. 